\title{
Modes of Production in a Materialist Conception of History
}

\author{
...the extremely dubious speculative juggling, \\ with the concepts and terms of the materialist \\ method, which has under the pens of some of our \\ Marxists transplanted the methods of formalism \\ into the domain of the materialist dialectic; \\ which has led to reducing the task to rendering \\ defi nitions and classifi cations more precise and \\ to splitting empty abstractions into four equally \\ empty parts; in short, has adulterated Marxism \\ by means of the indecently elegant mannerisms \\ of Kantian epigones. It is a silly thing indeed \\ endlessly to sharpen or resharpen an instrument, \\ to chip away Marxist steel when the task \\ is to apply the instrument in working over the \\ raw material! (Leon Trotsky)
}

\subsection{The retreat into historical formalism}

In his polemic with Dühring, Engels described the theory of surplus-value and the materialistic conception of history as the 'two great discoveries' of Marx, through which were established the scientific foundations of socialism. Modern materialism, wrote Engels, characterised history as a 'process of evolution' and set itself the task of discovering its 'laws of motion'. In one of the best reviews of Capital to appear at that time, a bourgeois economist Kaufmann repeated the point to Marx's approval: Marx treats the social movement 'as a process of natural history governed by laws'. ${ }^{2}$ In a famous resumé of his conception of history, written closer to our time, Braudel describes Marx as the originator of 'historical models' ${ }^{3}$ In their own way, these writers implied, in a language borrowed from the sciences of their time, that social phenomena like the phenomena of nature are scientifi cally penetrable, and that we owe the recognition of this fact to the work of Marx. Between the period from which this discovery dates and our own period, roughly in the last hundred years, the foundations of the older traditional conceptions of history collapsed as rapidly as the inherited conceptions of matter. But there the analogy ends. On the ruins of substantialism, a new physics evolved at rapid speed, whereas the 'programme of a fully scientific history remains not merely to be realized, but even to be drafted'. 'In short, the materialist conception of history did not actually produce a specifically materialist history.

In a sense, this abortion is not difficult to understand. Later in his life, Engels repeatedly noted in his correspondences that the younger elements attracted to Marxism saw in its theory, 'historical materialism', the summary of established results or points of arrival. In their conception, between historical materialism and materialist history there was a relation of immediate identity or implicit spontaneous derivation. Liberal-bourgeois historiography of that time and later proceeded as if theory could be derived from 'facts'; in this positivist conception, 'facts' were objects outside theory, constituted, like matter, independently of consciousness. For vulgar Marxism, infected by the illusion which Engels noted, history, already endowed with its theory ('historical 
materialism'), consisted in the application of this theory to 'facts'. By its vulgar conception of historical materialism this tendency implicitly threatened to submerge the scientific possibilities contained in Marx's conception of history in a quasi-positivism for which theory was latent in an objective succession of immutable facts. If such a premise were accepted, only minor differences remained: for positivism, the collection of those facts would lead spontaneously to the framing of general 'laws'; for the vulgar tendencies in Marxism these 'laws' were already known, and the task of history lay in their verification by 'facts'.

In fact, as we know, ${ }^{7}$ it was this convergence which became central to the Marxism of that period. For Marx himself, the task of scientific history consisted in the determination of the laws regulating the movement of different epochs of history, their 'laws of motion' as they were called after the example of the natural sciences. Vulgar Marxism abdicated this task for a less ambitious programme of verifying 'laws' already implicit, as it supposed, in the materialist conception of history. Whereas Marx had noted, as one of the points 'not to be forgotten', that is, to be investigated in future by him or others, the 'dialectic of the concepts productive force and relation of production, a dialectic whose boundaries are to be determined', ${ }^{8}$ a whole tradition from Plekhanov to Stalin argued with more assurance. Reverting to a naturalistic conception of history that Engels himself had explicitly rejected in the Dialectics of Nature (see the note on 'causality'), Plekhanov wrote: 'We now know that the development of the productive forces, which in the final analysis determines the development of all social relations, is determined by the properties of the geographical environment'. ${ }^{\circ}$ Reared in a Plekhanovist tradition, as so many of the other Bolsheviks were, but with a singular capacity for vulgarisation, Stalin would tell the party-cadre many years later, 'first the productive forces of society change and develop, and then, depending on these changes and in conformity with them, men's relations of production, their economic relations change'. Marx had been emphatic that abstract laws do not exist in history, that the laws of motion which operate in history are historically determinate laws. He indicated thereby that the scientific conception of history could be concretised only through the process of establishing these laws, specific to each epoch, and their corresponding categories. In other terms, through a process of producing concepts on the same level of historical 'concreteness' as the concepts of 'value', 'capital' and 'commodity-fetishism'. The 'laws' which Plekhanov and Stalin proposed were laws of the historical process in general.

The tradition of vulgar Marxism which drew its earliest sources of energy from the Marxism of the Second International, crystallised only under the domination of Stalin. Stalinism uprooted not only the proletarian orientations of Marxism, but its scientifi c foundations as well. For the dialectic as the principle of rigorous scientific investigation of historical processes - it was, after all, this rational dialectic that was 'a scandal and abomination to bourgeoisdom and its doctrinaire professors ${ }^{\prime 10}$ - Stalinism substituted the 'dialectic' as a cosmological principle prior to, and independent of, science. For the materialist conception of history, it substituted a theory of history 'in general', 
'converting historical epochs into a logical succession of inflexible social categories'."

Finally, this rubber-stamp conception of history it represented as a history déjà constituée, open therefore only to the procedures of verification. This lifeless bureaucratic conception, steeped in the methods of formalism, produced a history emptied of any specifi cally historical content, reduced by the forced march of simple formal abstractions to the meagre ration of a few volatile categories. Within five decades of Marx's death, the history written by the Stalinists became as opaque and dream-like, and hardly as exciting, as the fantasies of Surrealism.

Superficially these conceptions seemed to conflict, to clash sharply: the cosmological

dialectic asserted a principle of continuous flux in the vast ambit of the Universe; 'historical materialism', by contrast, proposed a principle of eternal recurrence, of the endless repetition of essentially identical mechanisms. Yet beneath this apparent conflict, idealism provided the deeper connection between these conceptions, in the idea, found both in the Academy's conception of history' ${ }^{12}$ and, much later, in abstract, systematising rationalism, ${ }^{13}$ that reason abolishes the chaotic flux of the empirical order when it grasps those abstract principles of necessity which are its deeper rational foundations. The

Academy sought these principles in the geometric layout of the heavens and in the mathematical forms associated with the different material elements. At a certain stage in its evolution, Greek thought deprived history of any intrinsic signifi cance. 'It became interested only to the extent that history offered clues to the nature of the enduring realities' ${ }^{14}$ To its cosmological conception of the dialectic Stalinism thus welded a cosmological conception of history, the ancestry of which lay not in Marx but in the whole tradition of metaphysics beginning with the Academy.

In their Stalinist determination, the basic categories of the materialist conception functioned as abstractions akin to Platonic Ideas. ${ }^{.5}$ The full impact of this paradox is driven home when we compare this formalist construction of history, entirely metaphysical in character, to the real, if limited, progress of the politically domesticated currents of 'academic' history. The pioneers who explored, colonised and subjugated the 'continent' of history discovered by Marx were not Marxists, by and large: Rostovtzeff, Mickwitz, Ostrogorsky, Pirenne, Kato Shigeshi, Hamilton, Goitein. ${ }^{16}$ Moreover, the 'most successful revolutionary group of modern historians' ${ }^{\prime \prime}$ around Annales bore only a marginal and indirect relation to Marxism. On this current, Marxism exerted its infl uence only at a distance, through the sociology of Weber and the writings of Sombart and Henri Sée. In fact, the reverse was true: the few consciously Marxist historians who grew up in this period were largely formed, to one degree or another, in connection with Annales: notably, Labrousse, Lefebvre, Vilar, Pach, Kula.19 This strictly professional history, not known for purely scholastic disquisitions on 'modes of production' and 'social formations', came far closer to the conceptions of Marx than the whole tradition of abstract historical formalism which passed for 'Marxism' and which, in the period of its confident domination, decisively shaped all later discussions of the 'mode 
of production'.

\subsection{Produktionsweise as 'labour-process' and 'epoch of production'}

A summary glance at the Grundrisse or Capital would show that Marx ascribed two distinct meanings to Produktionsweise [mode of production]. According to one of these, it was indistinguishable from the labour-process [Arbeitsprozess]', or what Lenin would sometimes call the 'technical process of production'. For example, in a brief reference to the domestic system, Marx writes:

The manufacturer in the French silk industry and in the English hosiery and lace industries was mostly but nominally a manufacturer until the middle of the nineteenth century. In point of fact, he was merely a merchant, who let the weavers carry on in their old unorganised way and exerted only a merchant's control, for that was for whom they really worked. This system presents everywhere an obstacle to the real capitalist mode of production and goes under with its development. Without revolutionising the mode of production, it only worsens the condition of the direct producers, turns them into mere wage-workers and proletarians under conditions worse than those under the immediate control of capital, and appropriates their surplus-labour on the basis of the old mode of production. ${ }^{20}$

When capital concentrates these scattered producers into one manufactory, it 'no longer leaves them in the mode of production found already in existence, establishing its power on that basis, but rather creates a mode of production corresponding to itself, as its basis. It posits the concentration of the workers in production...'. ${ }^{21}$ When Lenin describes this process of the subordination of the simple-commodity producer by capital, his vocabulary is more precise: 'The subordination begins with merchant's and usury capital, then grows into industrial capitalism, which in its turn is at first technically quite primitive, and does not differ in any way from the old systems of production - which is still based on hand labour and on the dominant handicraft industries...' ${ }^{2}$ For Lenin, this incipient 'industrial capitalism' which evolves out of the merchant's domination over the small producer is quite compatible with the 'system of production' inherited from small-scale handicraft industries. In this form of incipient capitalism, capital operates on an inherited labour process. When he describes this phenomenon, Marx writes: 'Here then the mode of production is not yet determined by capital, but rather found on hand by it',; ${ }^{\prime 3}$ whereas Lenin prefers to say, 'Capital always takes the technical process of production as it finds it, and only subsequently subjects it to technical transformation'. ${ }^{24}$ Again, in the sections dealing with relative surplus-value in Capital, Volume I, we find Marx writing: 'With regard to the mode of production itself, manufacture, in its strict meaning, is hardly to be distinguished, in its earliest stages, from the handicraft trades of the guilds, otherwise than by the greater number of workmen simultaneously employed by one and the same individual capital' ${ }^{25}$

When surplus-value has to be produced by the conversion of necessary labour into surplus-labour, it by no means suffi ces for capital to take over the labour-process in the form under which it has been historically handed down...The technical and social conditions of the process, and consequently the very mode of production must be revolutionised before the productiveness 
of labour can be increased..$^{26}$

Elsewhere in these sections, he writes that an increase in the productivity of labour posits as its condition a revolution in the 'mode of production and the labour-process itself'. When he says in the Grundrisse that 'agriculture forms a mode of production sui generis...', ${ }^{27}$ he means that it is defined by technical conditions peculiar to itself.

In various other passages where Marx made more general statements about the various stages of social development, Produktionsweise fi gured in a broader and more specifically historical meaning. Modes of production are variously called: 'forms of production'; ; 'forms of the social process of production'; 'epochs in the economic development of society';,;9 'epochs of production'; $;$ ';0 'periods of production' ${ }^{31}$ or, finally, 'historical organizations of production' ${ }^{.22}$ Here, the 'mode of production' figures as a 'social form of production' or 'social form of the production process' ${ }^{3 .}$

\subsection{Levels of abstraction in historical materialism}

2.3.1. Wage-labour as abstract determination and determinate abstraction

All the various tendencies of that abstract scholastic formalism which dominated Marxist theory much later accepted the implicit premise that a scientific history could be derived spontaneously from the materialist conception. In other words, the unity of these various currents lay essentially in a Ricardian methodology of 'forced abstractions'. ${ }^{.4}$

The definition of the different epochs of production distinguished by Marx required only a closer examination of their specific 'relations of production', which were nothing else than the various forms which the subjugation of labour assumed historically. 'Our definition will characterize feudalism primarily as a "mode of production"', wrote Dobb in his major work of historical interpretation. 'As such it will be virtually identical with what we generally mean by serfdom...'. ${ }^{35}$ As he would explain later in his debate with Sweezy, by 'serfdom' was meant 'exploitation of the producer by virtue of direct politico-legal compulsion', or 'coercive extraction of surplus labour' ${ }^{36}$ According to this formal abstractionism, modes of production were deducible, by a relation of 'virtual identity', from the given forms of exploitation of labour. These forms of exploitation, the so-called 'relations of production', were the independent variables of the materialist conception of history.

This conception, quite unexceptionable as it appears, became one of the most widespread and persistent illusions of vulgar Marxism. Although neither Marx nor Engels ever consciously refl ected on the nature of their categories - the fact that Marx distinguished implicitly between 'simply formal abstractions' and 'true abstractions', that he saw in his failure to carry abstraction 'far enough' the secret of Ricardo's confusions on 'value', that he himself subjected 'wage-labour' to a careful and painstaking analysis - all go to indicate that, in the materialist conception, the process of investigating and defining the 'relations of production' in any given epoch was far more complicated that Dobb seemed to imagine. 
To begin with 'wage-labour': in the dominant inherited notion, a wage-labourer is one who, divorced from any means of subsistence, is forced to sell her labour-power to others. 'Wage-labour', in this vulgar definition, is dispossessed labour, labour divorced from the means of production, with labour-power as a commodity. When Dobb defined capitalism on a model symmetrical to his definition of feudalism, he called it 'a system under which labour-power has itself become a commodity, bought and sold on the market like any other object of exchange' ${ }^{\prime}{ }^{37}$ In this definition of capitalist production, 'wage-labour' figures as the commodity labour-power, that is, as a simple category.

Marx defined 'simple categories' as those which were common to several epochs of production. In this simple determination, 'wage-labour', that is, the commodity labour-power, was known under various forms of social production before the capitalist epoch. Duby tells us that 'from the very earliest years of the thirteenth century, the administrators of the estates of the bishop of Winchester spent hundreds of pounds every year on wages'. Moreover, 'on the lands of Worcester Abbey the growth of the demesne economy was entirely achieved by taking on wage labor...The accounts of Henry de Bray, a knight of no great wealth, show that men subject to labour service played hardly any part in the cultivation of the demesne, which was wholly worked by hired labour'. ${ }^{38}$

In accordance with the requirements of capitalist production, 'wage-labour', in this simple determination as the commodity labour-power, was the necessary basis of capitalism as the generalised form of social production. Within certain limits, the mobility of labour-power became as essential to the laws of motion of capital as the ability of capital itself to operate on a world-scale. But the historical specifi city of wage-labour, its character as a specifi cally bourgeois relation of production, its position as a historically determinate abstraction equivalent to the abstractions 'capital' and 'commodity-fetishism' - derived from quite other mechanisms than this mere generalisation of the labour-power commodity. At this deeper level of abstraction, where it now fi gured, in the process of Marx's analysis, as a 'concrete' category, ${ }^{39}$ wage-labour was, for Marx, capital-positing, capital-creating labour. 'Wage labour, here, in the strict economic sense,' Marx wrote, 'is capital-positing, capital-producing labour' ${ }^{\text {an }}$ In a methodology of forced abstractions, which identified relations of production with particular forms of exploitation, the concept of 'historical specificity' was radically impoverished. Sweezy, for example, found Dobb's position unacceptable; he argued that there was nothing specifi cally feudal in the 'exploitation of producers by virtue of direct politico-legal compulsion'. ${ }^{\text {"n }}$ To this, Dobb replied that the elements of such compulsion do occur in a subordinate and incidental role in various other forms of economy: 'if [these elements] are merely incidental and subordinate, their presence no more suffices to constitute [the form of economy in question] as feudal than does the incidental existence of hired wage-labour suffi ce to constitute a particular society capitalist'. ${ }^{2}$ In other terms, if we follow out the logic of this argument, what makes an economy 'capitalist' is the statistical preponderance of the simple 
abstraction 'labour-power as a commodity'. A simple category becomes a historically determinate category when it becomes historically preponderant.

This failure to understand 'wage-labour' at the same level of abstraction as Marx, in the 'strict economic sense' which Marx gave it, that is, as abstract, value-producing labour, hence as labour which already posits the elements of capitalist production, would lead Dobb to quite absurd positions. He would be compelled to argue, for example, that when some of the most deeply entrenched feudal estates of thirteenth-century England often based their production mainly or entirely on paid labour ('wage-labour' in Dobb's sense), specifically capitalist relations of production were established ${ }^{* 3}$ He would have to hold that the Russian feudal estates which utilised slave-labour in the sixteenth and seventeenth centuries" operated within the framework of a 'slave mode of production'. He would have to hold that wherever in history the extraction of surplus-labour was based on 'coercion', feudal relations of production predominated, or 'coexisted' according to the currently fashionable conceptions.

\subsubsection{Serf-owning capital}

In fact, Dobb himself might have found several clear indications in the revolutionaryMarxist tradition refuting his law of the 'virtual identity' of forms of exploitation and relations of production. Analysing the pottery industry of Moscow gubernia, characterised by the Narodniks as a 'purely domestic' industry, Lenin wrote:

The relations in this industry are bourgeois...We see how a minority, owning larger and more profi table establishments, accumulate 'savings', while the majority are ruined...It is obvious and inevitable that the latter should be enslaved to the former - inevitable precisely because of the capitalist character of the given production relations... Do not think that this exploitation, this oppression is any less marked because relations of this kind are still poorly developed, because the accumulation of capital, accompanying the ruination of the producers, is negligible. Quite the contrary. This only leads to cruder, serfforms of exploitation, to a situation where capital, not yet able to subjugate the worker directly, by the mere purchase of his labourpower at its value, enmeshes him in a veritable net of usurious extortion, binds him to itself by kulak methods, and as a result robs him not only of the surplus-value, but of an enormous part of his wages too.... ${ }^{5}$ In this industry, then, specifically capitalist relations of production were expressed and mediated through 'serf forms of exploitation'. Against Struve, Lenin wrote elsewhere:

The argument is based on extremely strange methods that are not Marxist at all. A comparison is made between 'bondage' and 'differentiation' as between two independent special 'systems'... This bondage which he has now demolished as retrogressive is nothing but the initial manifestation of capitalism in agriculture...It is purely capitalist in essence, and the entire 
peculiarity consists in the fact that this initial, embryonic form of capitalist relations is totally enmeshed in the feudal relations of former times: here there is no free contract, but a forced deal...46

In these passages, Lenin argued, in other words, that as simple-commodity producers are subordinated to the power of capital, in town or village, and specifically bourgeois relations of production develop, far from transforming bondage and serf-forms of exploitation into specifically capitalist forms of exploitation, i.e., those forms which correspond to the 'classical, adequate mode of production of capital', these new relations of production, founded on capital, intensify the existing backward forms of exploitation: these forms remain 'feudal' or 'semi-feudal' in character, while the relations of production acquire a bourgeois character. ${ }^{47}$ Because Lenin understood this mechanism, he could refer elsewhere to 'semi-feudal forms of appropriation of surplus value', ${ }^{48}$ just as Kautsky refers, in the Agrarfrage, to the fact that in the early growth of capitalism in European silviculture, 'surplus-value' was produced by exploiting a feudally-subjugated labour-force [travail forcé de nature féodale]. ${ }^{4}$ Earlier than either Lenin or Kautsky, Marx himself spoke of the production of 'surplus-value' in the cotton-plantations of the American South. ${ }^{50}$ Although the translation of Moore and Aveling distorted the sense of this passage when it used 'surplus-labour' for Mehrwert, the meaning was abundantly clear to both Rosa Luxemburg and Preobrazhensky. Luxemburg, with this passage in mind, spoke of 'capitalist accumulation with forms of slavery and serfdom' persisting up until the 1860s in the American South, and, as late as her own day in Rumania, 'and various overseas colonies'. ${ }^{51}$ In his own commentary,

Preobrazhensky wrote, 'the important thing is that there are present all the prerequisites of surplus-value, except the last, which is characteristic of the development of capitalism - the transformation of labour-power into a commodity'; he proposed 'transitional forms of surplus-value' as a more precise characterisation.52 Again, in Capital Volume III, Marx referred to the evolution of merchant-capital in the ancient world transforming 'a patriarchal slave-system devoted to the production of immediate means of subsistence into one devoted to the production of surplus-value'. ${ }^{33}$ According to an edict of 1721, Peter the Great had allowed the Russian factory-owners to utilise serf-labour. 'But if the factory-owner could now carry on his business with the labour of serfs', wrote Pokrovsky, 'who prevented the serf-holder from establishing a factory?' To Pokrovsky the edict was one of the forerunners of 'bondage or landlord capitalism' . ${ }^{54}$ Analysing the land-question in Peru, Mariátegui wrote about the technically advanced capitalist latifundia on the coast, owned by US and British business, in which 'exploitation still rests on feudal practices and principles'. ${ }^{55}$ In its Theses on the Eastern Question adopted at the Fourth Congress, the colonial commission of the Comintern spoke of capitalism arising in the colonies 'on feudal foundations' and developing 'in distorted and incomplete transitional forms which give commercial capital predominance' ${ }^{56}$ Finally, outside the Marxist tradition, Hobson could refer to industrial profits which 'represented the surplus-value of slave or forced labour', ${ }^{57}$ and Barrington Moore to 'labor-repressive forms of capitalist agriculture' ${ }^{58}$ In all these varied instances - the subordination of the potters of Moscow province to merchant-capital, the production of cotton in the 
slave South, the expansion of landlord-capitalism in Rumanian agriculture or Petrine industry, the sugar-latifundia of coastal Peru - there was no question of identifying the 'mode of production' according to the character of the given forms or relations of exploitation. Nor did any of these instances involve a 'coexistence' of modes of production.

\subsubsection{The defining role of the laws of motion}

To identify the different kinds of motion is to identify the bodies themselves.

(Engels to Marx 1873)

Engels defined the dialectic as the 'science of the general laws of motion of the external world' ${ }^{.9}$ But the abstractness of the dialectic in this defi nition deprived it of its specifically revolutionary function in Marx. For Marx, as his approval of Kaufman's review indicates, the dialectic was, more specifi cally, a science of the laws of motion of the 'social process', profoundly historical by its very nature, not only in that it guided only the investigation of social (or historical) phenomena, but insofar as it denied that such phenomena could be understood according to abstract or historically indeterminate (social or historical) laws: 'in Marx's opinion', Kaufman wrote, 'every historical period has laws of its own' ${ }^{\text {co }}$ The dialectic in Capital was thus nothing else than the rigorous, systematic investigation of the laws of motion of capitalist production, in the course of which a series of simple abstractions ('wage-labour', money, etc.) were historically concretised as bourgeois relations of production, or abstractions determinate to capitalism as a mode of production; that is, reconstituted as 'concrete categories', as historically determinate social forms. It follows that modes of production are impenetrable at the level of simple abstractions. The process of 'true abstraction' is simultaneously a process of 'concretisation', of the definition of specific historical laws of motion. Isolating the enterprise of production under capitalism, Marx analysed these laws at two levels: at the level of each enterprise (or 'economic unit': Lenin) and at the level of the social totality of enterprises. If we generalise from this analysis, at its first level, the enterprise, an isolated entity, figures as a unit of production governed by specific laws which impose on it a determinate mode of economic behaviour, converting the given inherited forms of the labour-process into the form posited by their own motion. It follows that the different types of enterprise which form the basic cell of production in a given social form of economy are determined, in the first instance, as units of production, and only crystallise (that is, acquire their classical developed structure) in the determinate form of historically specifi c modes of organisation of the labour-process which posit a particular level of technique and specific historical forms of the appropriation of the objective conditions of labour. At the level of the economy of enterprises, the process of investigation traces those tendencies which derive from the behaviour of each enterprise at the level of all enterprises. In Marx, Capital, Volume I comprises the analysis of the enterprise (of capitalist production) as an isolated entity, as individual capital - of the production and accumulation of surplus-value and of the labour-process as a value-producing process, which Marx characterises as the 'direct process of the production of capital' or the 'immediate productive process'. The laws of the rising organic composition of capital and of 
the concentration and centralisation of capital are already implied in the motion of individual capital (of capital as an isolated enterprise). Volumes II and III derive the laws of motion of capital at higher levels of integration (social capital, many capitals) from the laws of motion of capital as an isolated entity, arriving fi nally at the transformation of surplus-value into profi $t$ and the law of the falling rate of profi $t$. The fi rst three parts of Volume III complete the definition of capitalism as a mode of production. Taken as a whole, across its various stages, the substance of Marx's analysis lies in its definition of the laws of motion of capitalist production: the production and accumulation of surplus-value, the revolutionisation of the labour-process, the production of relative surplus-value on the basis of a capitalisticallyconstituted labour-process, the compulsion to increase the productivity of labour, etc. The 'relations of capitalist production' are the relations which express and realise these laws of motion at different levels of the social process of production. They are, as Marx calls them in a polemic against Proudhon, 'all the economic relations which are merely the necessary relations of the particular mode of production'. As modes of production are only a definite totality of historical laws of motion, relations of production thus become a function of the given mode of production. The character of any defi nite type of production relations, is, in short, impossible to determine until these laws of motion are themselves determined.

Finally, apart from deriving the nature of production relations of a given type from the mode of production as such, the defi ning role of the laws of motion implies that the specifi c economic rhythms through which these laws become at once historically effective and verifi able are themselves purely derivative economic phenomena. Although phenomena of this order (trends, cycles, intercycles) are in some sense perceptible and open to statistical determination independently of any conception of those laws, of which they are simply the expression, their historical content remains indeterminate without a prior conceptualisation in economic theory. ${ }^{61}$ Lacking any determination in theory, they retain their character as empirical (quantitative) facts: on certain epistemological premises - observation as the origin of theory - they become therefore the basis for positing 'laws' of a purely fictitious nature, e.g., the 'acceleration principle' of neoclassical economic theory.

\subsubsection{The failure of abstraction in vulgar Marxism}

Even when the later Marxism broke with Stalinism politically, its theoretical conceptions were to a large extent still imprisoned in the deeper framework of a metaphysical-scholastic formalism, which deduced its 'modes of production' by forced abstraction from the simple categories present in various epochs of production. The classification of 'modes of production' which came to prevail on this basis resembled nothing so much as the Periodic Table of Mendeleiev, when the discovery of the structure of the atom had yet to explain the physical basis of that Table. The simple abstractions of Stalinist history, its 'inflexible social categories', functioned in the historical process as social substances, and this Newtonian conception of history was absorbed into the later Marxism, even when it modifi ed or rejected the established 
sequence of those elements. (In this sense, the 'linear notion of historical time' had always been a purely subsidiary characteristic of vulgar historical materialism.) In short, the naïve conception of 'relations of production' as forms of exploitation of labour, and the classification of 'modes of production' according to the simple formal identities which this equation yielded, remained essential links of continuity between the ossified pseudo-Marxism of the Stalinists and the 'critical' tendencies of modern Marxism.

The persistent underlying confusion between 'relations of production' and therefore, in this conception, 'modes of production', with the different mechanisms of surplus-labour extraction became the most characteristic symptom of this continuity of problematics in the more recent debates on the 'transition' and on the nature of imperialist world-economy. Despite their critical character, these debates produced no breakthroughs by way of a specifi cally Marxist analysis either of the decline of feudalism or of colonial history.

It was precisely in the backward countries subjugated to world-economy as colonies that the process of the mediation of capitalist (value-producing) relations of production by archaic ('precapitalist') forms of subjection of labour assumed historically unprecedented dimensions, while feudal relations of production figured predominantly in their pure form of commodity-feudalism. Insofar as these relationships were perceived by them, a number of Marxists conceptualised them, completely wrongly, as the structure of the 'social formations' themselves. The chaos of simple abstractions was overcome by them through the simple notion, today commonplace to the point of banality, that the colonial 'social formations' typically 'combined' a number of 'modes of production' (which was true, of course, but not at this level of abstraction).

The colonial countries were mainly dominated by two distinct forms of enterprise, radically different in their specifi c laws of motion and characteristic preoccupations, but converging in their external forms: on one side, in most of Latin America and parts of South-East Asia, feudal estates integrated into the network of world commodity-exchanges, estates which, in their external attributes, resembled capitalist enterprises insofar as the major share of their output was produced for national and international markets; on the other, in the West Indies, most of Africa and large sectors of Asia, capitalist fi rms operating mainly through archaic ('precapitalist') modes of labour-organisation at low and generally stagnant levels of technique. Isolated from their specifi c laws of motion, these enterprises disintegrate analytically into a single type, 'capitalist' or 'precapitalist' according to the specifi c formal appearances collapsing them together (for Frank, commodity-production; for Laclau, the prevalence of servitude of various forms)..$^{2}$ This collapsing together, from which followed the false conception of the colonial world as a 'sector', or unified totality of production-relations of one type, became one of the common premises in the debate started by the publication of Frank's book.

The whole challenge which the 'colonial question' poses for historical materialism lies in establishing these distinct economic rhythms and movements, in tracing their specific origins according to the conjuncture of world-economy, 
and fi nally in grasping their deeper connections. If the feudal enterprises of the colonial world functioned as commodity-producers, the explanation lies basically not in their historical position as colonial enterprises (that is, not in their determinate form and function as elements in a specific type of social formation), but in their specifi cally feudal character; and, if the capitalist enterprises which dominated most of colonial Africa and large parts of Asia utilised coercive forms of exploitation, we must ask whether the laws of motion of capital are not, within certain limits, compatible with 'barbarous forms of labour'.

Thus, neither the phenomena of colonial history nor the disintegration of feudalism could be subjected to a specifi cally Marxist analysis as long as relations of production were conceived in their abstract, one-sided determination as 'forms of exploitation'. For, on this premise, Marxists consciously or unconsciously denied the intrinsic connection between feudalism and commodityproduction, or between bondage and capitalism, which was established in given historical conditions. Once currency began to circulate on an expanding scale, the whole tendency of feudal production lay in the direction of its integration into circuits of commodity-exchange. Moreover, the whole history of colonialism in Africa was basically a history of capitalist enterprises subjugating peasant labour on specifi cally non-capitalist foundations. Both these phenomena, characterised by Marx as 'intermediate, hybrid forms [Mittelgattungen, Zwittergattungen] ${ }^{\prime \prime s}$ were historically never of purely limited scope or passing signifi cance. The 'second serfdom' engulfed most of Eastern Europe and large areas of Latin America, where it persisted for well over four centuries, longer than capitalism has existed in its classical form of large-scale socialised production; and the archaic barbarous forms of capitalist production itself appeared sporadically over a similar historical span - from the early origins of the 'domestic system' in medieval Europe, through the sugar plantations of Barbados in the seventeenth century, to the gold-mines of South Africa in the nineteenth, the agrarian colonate of Algeria, the Junker estates of Prussia, the tea plantations of Assam and sugar centrales of Cuba, or, fi nally, in our own century, the processing factories of coastal Peru, cotton fi elds of northern Mozambique or white settler-farms of Kenya. ${ }^{64}$

Constricted by their problematic of characterisation (of simple formal abstraction), the debates among Marxists perceived these facts in a purely one-sided, distorted way: that is, the facts were 'formulated' incorrectly even when they were perceived. Sweezy perceived a certain connection between the decay of feudalism and expanding commodity-relationships, but formulated the connection as a collapse of feudal economy. Dobb, and later, in Dobb's tradition, Laclau, perceived the link between commodity-production and the intensification of servitude, but concluded, from their famous 'virtual identity', that the market 'consolidated' the feudal economy. ${ }^{65}$ Frank perceived the intrinsic bond which tied the feudal haciendas to the market, only to dissolve it immediately by defi ning them as 'capitalist'. ${ }^{\circ}$ Bettelheim argued, correctly, that the exploitation of colonial peasants by capitalist fi rms had to be 'rooted at the level of production', only to reconstitute the relation at 
the level of exchange in saying that these peasants sold not their labour-power but their products. . The new currents of 'political economy' infl uenced by Arrighi and Amin correctly defined the role of the 'labour-reserves' in Africa in relation to the needs of capital accumulation, only to characterise them as distinct 'modes of production' perpetuated by capital. ${ }^{\text {ss }}$

Marx himself had proposed the view that 'commerce has a more or less dissolving influence everywhere on the producing organization, which it finds at hand and whose different forms are mainly carried on with a view to use-value' ${ }^{69}$ When the world-market crystallised after the revolution of the sixteenth century, these 'producing organizations' or enterprises, as we have called them, consisted mainly of two types: feudal estates and independent peasant family-labour farms. The progressive integration of these types of enterprise into commodity-circuits convulsed both, but only on the longer historical scale of several centuries. Both the feudal estates and the peasant farms entered a process of dissolution, but neither 'collapsed' or disappeared immediately. Moreover, this process of dissolution acquired, in the case of feudalism, a 'combined' character. Feudal production (the feudal mode of production) both crystallised and decayed within the framework of expanding marketrelations: the feudal estate both acquired its 'classical', fully developed, structure and reached its inherent limits as a commodity-producing enterprise. By contrast to both forms, the slave-plantations, normally regarded as 'precapitalist', disintegrated by an entirely different process, not immediately connected with the expanding volume of exchanges in whose vortex they were, in fact, born as 'centres of commercial speculation'.

\subsection{Reading history backwards}

When the revolutionary-Marxist tradition took up the analysis of the worldeconomy early in the present century, the context was set by an international division of labour centred on the requirements of capital-reproduction on the basis of large-scale industrial enterprises. The classical conception which now evolved in the writings of Lenin, Luxemburg and Bukharin saw in the major tendencies of evolution of the world economy the separate phases of the reproduction-process of capital: the conversion of value into money and of money, as the pure form of value, into capital. The debate which began closer to our own period about the early phases of evolution of the world-economy inherited this classical conception and converted its points of arrival into points of departure. If, to the Marxists of the Second and Third Internationals, the contemporary world-market was an entirely capitalist phenomenon, it seemed evident to Frank that the world-economy had been capitalist from its inception. So deeply entrenched was this notion, that, even when he disputed Frank's position that capitalism prevailed in Peru or Chile from the earliest stages of the Spanish colonisation, Laclau accepted his premise that metropolitanindustrial capital provided the major impulse behind this process of colonisation. For Frank, colonisation converted the countries of Latin America into 'sources for metropolitan capital accumulation and development'; for Laclau, too, the world-economy was, from its inception, an expression of the accumulation-process: 'the growth of the system depends on the accumulation 
of capital, the rhythm of this accumulation depends on the average rate of profit, and the level of this rate depends in its turn on the consolidation and expansion of pre-capitalist relationships in the peripheral areas' ${ }^{70}$ Behind their formal dispute about 'characterisation', the two arguments shared this single premise: whether one characterised the forms of economy in Latin America as 'feudal' or as 'capitalist' - that is, whether one 'deduced' their character from one or other of the two simple abstractions specifi ed earlier the point was that the world-economy evolved in this period as a response to the expansion of industrial capitalism. If this was so evident both to Frank and Laclau, the only 'problem' which remained was the formal problem of characterisation: 'the problem is to define in each case the specifi city of the exploitative relationship in question' - which was no different from saying that there was in fact no problem at all, or that the problem was purely formal, because this so-called 'specifi city' was already self-evident at the level of the simple abstraction. For example, for the plantations, it required literally only a single sentence to establish this 'specificity': 'in the plantations of the West Indies', Laclau wrote, 'the economy was based on a mode of production constituted by slave labour'. ${ }^{\prime}$ It was as simple as that.

Inherent in this form of argument - not peculiar to Laclau or Frank, but deeply entrenched in the whole tradition of 'Marxism' inherited from the 1920sis the following underlying premise, which is inseparably bound up with the formal problematic of 'characterisation': in all phases of its evolution, the structure of the world-economy posits only one element of explanation, namely, the demands of capital-reproduction. From this, it follows that modes of production other than capital which coexist within the structure of that economy fi gure only as 'specific' forms of subjugation of labour perpetuated over time by the requirements of industrial accumulation. These are 'modes of production' entirely deprived of their own laws of motion, vegetating on the periphery of an industrialising Europe like a vast reserve of labour-power periodically called into action by the spasmodic expansions of metropolitan capital. For purposes of propaganda, it would be entirely adequate to relate the existence of slavery in the cotton plantations to the requirements of the English textile industry, or the intensified exploitation of serf-labour in the grain-exporting nations of Eastern Europe to the fact that capital requires a large volume of grain at low prices. But Marx was aware that a scientific enquiry was an entirely different sort of exercise to a propagandistic tract, and it was this awareness that initially distinguished Marxism from Ricardian and petit-bourgeois socialism.

\subsection{Slavery and the world-market}

\subsection{1. 'Slavery'}

To start with this 'mode of production constituted by slave labour', it is a striking fact, impossible to ignore, that within the Marxist tradition, as outside it, the slave-plantations of the American South were never always as simply characterised as Laclau imagines. For example: Marx wrote that in the English colonies which produced tobacco, cotton, sugar, the colonists acted 'like people, who, driven by motives of bourgeois production, wanted to produce commodities ...'. ${ }^{n}$ He described these plantations as enterprises 
of 'commercial speculation' in which 'a capitalist mode of production exists, if only in a formal sense...The business in which slaves are used is conducted by capitalists' ${ }^{73}$ He described the exploitation of slave-labour as a 'factor in a calculated and calculating system', driven by the compulsion to produce 'surplus value'.$^{74}$ Commenting on this passage, Preobrazhensky spoke of 'undeveloped, transitional forms of surplus-value, which are not completely characteristic of a developed capitalist mode of production' ${ }^{.5}$ On the other hand, for Kautsky, the slave-plantations of America were a form of 'large-scale production of a pre-capitalist type' ${ }^{.{ }^{6}}$ Lenin, who accepted this characterisation directly under Kautsky's infl uence, later argued, in a polemic on American agriculture, that there was really 'no foundation for the common practice [sic] of classifying the [slave] latifundia as capitalist enterprises', that these latifundia were 'frequently [sic] survivals of pre-capitalist relationships slave-owning, feudal or patriarchal' which typically manifested the lowest percentages of 'improved acreage'." Much more recently, in one of his books, Genovese argues that the 'slave regime in the British Caribbean bore the clear stamp of capitalist enterprise', and that sugar was grown on 'large plantations of a decidedly bourgeois type' run by 'capitalist slaveholders' ${ }^{\text {s }}$ But earlier, in his major work of interpretation, Genovese had also written, this time with reference to the American plantations, 'the planters were not mere capitalists [sic], they were pre-capitalist, quasi-aristocratic landowners who had to adjust their economy and ways of thinking to a capitalist world market...'. ${ }^{\text {rp }}$

In a review of the Frank-Laclau debate, Jay Mandle thought the plantations were 'intensely profit-oriented commercial enterprises' and the plantation owners 'profit-maximizing entrepreneurs', i.e. capitalists as we normally understand them, but added, to be on the safe side, that their exploitation of slave-labour made it 'impossible by Dobb's definition to classify them as capitalist'. ${ }^{\text {. }}$ In fact, as we know, with the single exception of Lenin, the major argument proposed by all other writers against classifying the slave-plantations as a form of capitalist enterprise was precisely that 'by Dobb's definition', by virtue of his 'virtual identity', they could not be so because they exploited slave labour.s" Lenin himself proposed a quite different argument, and one which, as we shall see in a moment, contained a substantial insight, namely, that the level of technique and the extensive character of such an enterprise were suffi cient to preclude their characterisation as 'capitalist' in the strict sense in which the various other types of agricultural enterprise in other zones of America were 'capitalist'. It would have made practically no sense for Lenin to have argued that the prevalence of slave labour as such made the plantations 'precapitalist', because, quite apart from his early descriptions of the various 'medieval' forms of capitalism prevalent in the Russian countryside, he also wrote, in that period: 'Our literature frequently contains too stereotyped an understanding of the theoretical proposition that capitalism requires the free, landless worker...'; this was true, Lenin argued, as 'indicating the main trend' (cf. Section 3.1 above where I referred to wage-labour in its simple determination, i.e., free labour, as the necessary basis for capitalism as the generalised form of social production), but agrarian capitalism was compatible 
with unfree labour at specific stages in its evolution..$^{s 2}$

To indicate only briefly, and entirely by way of hypothesis, the framework for a more rigorous Marxist understanding of the slave-plantations: we argued earlier that the analysis of a given historical form of production treats its constituent enterprise basically as a unit of production, an entity governed by specifi c economic laws, and regards the emergence of its specifi c form of organisation of the labour-process, the process which corresponds to its laws of motion, only as a moment of its 'crystallisation'. The slave-plantations were commodity-producing enterprises characterised by speculative investments ('centres of commercial speculation') in the production of absolute surplus-value on the basis of landed property. Production was carried on in such enterprises at low, 'capital-specific' techniques which posited enlarged simple cooperation subject to economies of scale..$^{.3}$ Accumulation in this form of speculative capitalist enterprise asserted itself only in the long run, as a relatively slow and mainly sporadic tendency dominated by feudal modes of consumption. The progress of such an enterprise would thus present the external aspect of a series of simple reproduction-cycles expanding slowly to higher levels according to a discontinuous and bunched rhythm of investments. At the level of all enterprises, this purely quantitative character of accumulations and its 'natural' basis in the ownership of land (here, the capitalist and landlord being one and same person, as Marx indicated) would progressively convert the excess of commodity-values over prices of production inherent in the low technical composition of capitals into 'surplus-profits' appropriated by the slaveowners themselves as 'absolute rent'. . $^{\mathrm{s}}$ For we know that historically plantation land of a specifi c fertility would become, progressively a monopoly of only the most substantial or at least earlier-established slaveowners, and thus present a 'barrier' to the free investment of capital, as much as land incorporated as feudal property constituted such a barrier and thus generated 'absolute rent'. It follows that, even when cost-prices rose as the natural fertility of the soil declined through intensive exploitation at stagnant levels of technique, a crisis of profitability could be postponed indefinitely for a certain range of market-prices.

This specific form of enterprise therefore differs from the classical form of capitalist enterprise mainly in its lower intensity of accumulation and in the fact that accumulation is here compatible with a constant composition of capital, and therefore with stagnant or declining levels of labour-productivity. Increases in the rate of exploitation depend not on the conversion of necessary labour into surplus-labour, i.e. the production of relative surplus-value, but on an intensifi cation of labour or on a lengthening of the working-day to the limits of physical endurance. The self-expansion of value no longer figures as an entirely autonomous and dominating force compelling each enterprise to reduce cost-prices to a minimum, but acquires a purely relative and sporadic existence as a function of feudally-dominated habits of consumption and display. Plantation-profits, we know, financed not only the (quantitative) expansion of the enterprise itself, but, probably to an even greater extent, peerages, marriage-alliances, seats in parliament and the purchase of feudal properties. ${ }^{87}$ In short, the slave-plantations were capitalist enterprises of a patriarchal 
and feudal character producing absolute surplus-value on the basis of slave-labour and a monopoly in land. This heterogeneous and, as it appears, disarticulated nature of the slave-plantation generated a series of contradictory images when the early Marxist tradition, not equipped with the same abundance of material available today, attempted its first characterisations.

\subsubsection{The nascent world-market}

The sugar produced by enterprises of this nature in the Caribbean and exported by them mainly to England, France and Holland, became the leading item of a major re-export trade within Europe itself in the course mainly of the seventeenth century. ${ }^{s}$ Given the circumscribed and localised distribution of a specifically bourgeois class in Europe at that time, the growth of this re-export trade suggests that the demand for sugar and other types of plantation-produce was not confi ned exclusively to the established mercantile or incipient industrial-capitalist classes of England or Holland. Moreover, we know also that the period when English sugar displaced Brazilian sugar from the markets of northern Europe was itself a period of rapid English commercial expansion in the Baltic. The deeper meaning of this connection becomes evident when we note that, throughout this period, and in fact much earlier, Europe had been divided into three more-or-less distinct price-zones whose centres of gravity tended to fl uctuate while preserving a certain basic uniformity. On the eve of the seventeenth century, according to the price series constructed by Braudel and Spooner, the price of grain in England, France or Holland was 200-300\% higher than the price of Polish grain. ${ }^{.9}$ The growing volume of grain-exports from the port of Danzig had become a crucial mechanism in stabilising grain-prices in those countries in the period of rapid demographic reconstruction and currency-depreciation which began around 1570. So intense was this integration of Polish grain into the economy of Western Europe that Pokrovsky wrote in the History of Russia: 'The price of rye in Danzig determined the cost of living in Madrid or Lisbon', Marian Małowist tells us that 'every disturbance in the delivery of grain from the coasts of the Baltic, especially from Poland, produced a rise in the cost of living in Holland and other provinces of the Low Countries...'. 'But how were the English, Dutch or Portuguese to pay for these imports? Before the export of English textiles to Portugal helped to balance England's trade with the Baltic by sucking bullion out of Portugal, ${ }^{n z}$ this role of payments-mechanism in the expanding grain-trade devolved partly on the export wool-trade, which required a massive drive to expropriate the domestic peasantry, and partly on the re-export of colonial produce to the feudal classes of Eastern Europe. From this, we can draw two conclusions. Firstly, the demand which sustained production in the capitalist slave-enterprises of the West Indies depended to some degree on the expansion of feudal incomes in the grainexporting

zones of Eastern Europe. Secondly, these enterprises were compelled to operate within a framework of mercantilist control because colonial produce, as an element of feudal consumption, became one important means of fi nancing grain-imports from the feudal estates. In the seventeenth century, at any rate, the world-economy presented a vastly different picture from the industrially-dominated world-market of the nineteenth which formed 
the basis for the early Marxist theories of imperialism. For, at that stage, the structure of world-exchanges linked the capitalist slave-plantations of the Atlantic to feudal estates in Poland through a complicated network of basically mercantile and fi nancial interests centred in Amsterdam and London. Each of these enterprises fitted into this structure of the world-economy as specifi c autonomous units of production driven by their own laws of motion. If this is evident for the slaveowners, 'driven by motives of bourgeois production', it now has to be established for the Polish estates.

\subsection{Feudal production}

\subsubsection{The estate}

The feudal economy was an economy of consumption based on a level of technique that was so rudimentary that a single aristocratic household required for its support a vast arable area. In the earliest period for which estateinventories become available, the ratio of output to seed barely exceeded 2:1.

In Europe, on the eve of the fourteenth century, after a long swing of slow agricultural progress connected with improvements in ploughing technique and a gradually expanding triennial rotation, maximum grain-yields oscillated around 4:1. Finally, as late as the eighteenth century, both in the fertile Po Valley of northern Italy and in the black-earth region of Russia, the major cereals gave a yield of 3-5.1.93 For this low productivity of labour, the estate, the basic enterprise of feudal production, compensated by practising an extensive economy. As the level of technique progressed only slowly, over several centuries, as our figures indicate, the estate's output was a function of the surface in production, and the surface which the lord could bring into production in any given period was a function of the disposable mass of labour-power. ${ }^{9 *}$ The limits to the mobilisation of this mass of labour-power, when not determined technically by the available quantity of draught-animals, were imposed socially by the relation of forces, the possibility of fl ight and the relative degree of 'overpopulation'. The average volume of output was thus determined ultimately by the socially disposable mass of labourtime. ${ }^{95}$

As a form of enterprise, the feudal estate normally consisted of separate manorial units related metabolically as parts of a single economic organism centred on the lord's household. The structure of these units varied from those in which demesne arable was of no significance and feudal incomes consisted mainly of monetary payments based on tithes and seigneurial rights [seigneurie banale], to others in which demesne economy based on slave- or serf-labour predominated. In the feudal epoch as a whole, the estate's economy generated two relatively distinct modes of organisation of the labour-process. The first of these, defined by the insignificance of demesne, posited a higher elasticity of surplus in the peasant-sector and a distribution of arable between peasantholdings and demesne, which conferred on the former the character of a sector of small peasant-production, with the peasants disposing of the whole of their labour-time; here the rate of feudal exploitation was not immediately evident in the ratio of the two arables. In the second mode of organisation of the labour-process the peasant-holding was a 'subsistence plot' or 'wage in kind $^{\prime,}$, and the totality of these holdings a sector of simple reproduction;"; here, the distribution of the peasants' necessary and surplus labour-time 
would tend to coincide directly with the distribution of arable between peasantholdings and lord's demesne. Taking the feudal epoch as a whole, the peasant-holdings thus figured in two determinate forms and functions: as small peasant-farms capable of generating a more or less substantial surplus over the peasants' immediate requirements of consumption, and as subsistence plots adapted to the reproduction of labour-power. As the organisation of the labour-process became effective within the framework of the manor, and as most estates comprised several manors, the ratio of demesne arable to peasant arable would tend to fl uctuate quite sharply between the different manors, estates and regions, and the size of peasant holdings [manses] to vary even more sharply at any given time. In general, a casual survey suggests that the area occupied by demesne varied between $13 \%$ and $45 \%$ of the total area of a given estate or manor, with a tendency to vary inversely with the size of these units; while peasant-holdings ranged from miniscule plots of 10 acres or less to substantial farms of 100 acres. If we now ask which of these forms constituted the classical or fully developed structure of the feudal enterprise, the answer should not be diffi cult: the enterprise only 'crystallised', that is, acquired its classical structure, when the ratio of the peasants' necessary to surplus labour-time was directly refl ected in the distribution of arable between demesne and peasant-holding. In other words, the form of organisation of the labour-process specific to the feudal mode of production in its developed form would be one which permitted the lord to assert complete control over the labour-process itself - in which the peasant-holdings assumed the form of, and functioned as, a sector of simple reproduction.

Within the framework of this type of economy, and regardless of the structure of the labour-process, the production of wealth was subordinated to habits of generosity, display and consumption. Pirenne maintained that, in the 'patriarchal' organisation of the big estates, the notion of 'profits' in the sense of value which expands itself, was utterly alien;"s as we know, the only 'investments' which such an enterprise ever undertook were those which were strictly necessary for the requirements of simple reproduction (and mainly, the periodic reconstitution of manorial livestock). In this sense, the lord's consumption constituted the only 'motor-force' of expansion in the feudal economy.9

Yet Pirenne's conception of the estate as a 'patriarchal' organisation is misleading (and did, in fact, mislead Sweezy). The determining role of consumption did not imply an ideal of isolationism, or any basic economic irrationality. We know that, as the twelfth century progressed, a large number of agricultural treatises appeared which regarded agriculture as a 'mechanical art' worthy of scientifi c interest and capable of systematic improvement. We know that, in gradually going over to a triennial rotation, the estates spread the risks of a bad harvest more widely, for in years when excessive moisture destroyed the winter-crops, spring-grain would come to the rescue. Above all, of course, we know that when the demand for agricultural produce expanded, demesne-cultivation accounted for a major share of the marketed output. The fact that, in phases of rapid infl ation, estates would tend to convert from fi xed 
monetary payments to 'direct management' implies that some mechanism of 'opportunity-cost' calculation operated. But the spread of these 'business-like' attitudes, as they were characterised by Sweezy, ${ }^{100}$ was not only compatible with the character of the feudal economy as an economy of consumption, but inseparably tied to it. In a sense, this compatibility and basic link between feudal consumption and business-like attitudes is the central point. The consumption-

requirements of the nobility and the perpetual need to adjust the level of income to rates of consumption were the most powerful determinants in drawing both lord and peasant into production for the market: the lord directly through the consolidation of a demesne-economy, the peasant indirectly through the expanding weight of monetary payments. In phases of ascending production for the market (England c. 1250, Poland and Hungary c. 1600) it is quite probable that most commodity-producing estates rarely sold less than half their net output. For example, on the 32 dependent manors of the Bishop of Winchester for which detailed time-series are available, in average years close to $80 \%$ of net output was sold; on 6 of the Duchy of Lancaster's manors in Wiltshire, $90 \%{ }^{101}$ Even outside periods of high grain prices, the proportion of marketed output was fairly high: $c .1150$ one of the manors of the abbey of Cluny was selling the whole of its wheat-output and $33 \%$ of its output of rye; ${ }^{102}$ two hundred years later, when demesne-production was in partial decline in the West, but the full impact of the incipient recession had still to come, a small estate in Essex for which fi gures are available, reserved $21 \%$ of its total wheat-receipts for seed, paid $19 \%$ in wages to workers on the demesne, sent $23 \%$ to the lord's household for direct consumption, and sold the remaining $30 \%$, which comes to $37 \%$ of net output (deducting seed). ${ }^{103}$ If these preliminary examples do not suffi ce, a different order of evidence might be used. The 'maximisation of sales' became a major slogan of the various treatises addressed to the Russian nobility of the eighteenth century. According to Confino,

the basic idea underlying the economic treatises of this period was the realization of profi ts and expansion of feudal incomes: these became the major goal of the estate's economic activity, the main obsession of the pomescik and the chief duty of the bailiffs...Ryckov's book of instructions to estate-managers began, 'Our main interest in this book is how the income and profi ts of the lord may be expanded' ${ }^{104}$

In another treatise, Bolotov described the most competent estate-managers as those who could maximise the volume of sales at the best price, while ensuring the immediate consumption-needs of the household. ${ }^{105}$

Far from facing the 'alternatives' of producing for the market or producing for ' $u s e^{\prime},{ }^{106}$ most estates were organised according to a certain internal specialisation, with some manorial units producing mainly or entirely for the market and others for household-consumption. In both aspects, the organisation of the estate was a function of the socially determined consumption needs of the lords. In their consciousness, commercial production and feudal 'subsistence' were not separate, confl icting aspects of their social practice as a class, for, as one of the Russian treatises indicated, the production of feudal profi ts was geared to the goal of feudal consumption. ${ }^{107}$ 
This preliminary outline of the basic characteristics of the estate is sufficient to imply two conclusions. (i) Production for the market did not entail competition between the different enterprises. What was mainly important to this type of enterprise was the preservation of a certain proportionality between income and consumption, not the rapid expansion of incomes from one year to the next on the example of a capitalist firm. In a capitalist economy, the market exerts its domination over each individual enterprise by compelling it to produce within the limits of a socially average level of productivity. The existence of this social average posits a mechanism of cost-calculation which was absent in conditions of feudal production. To be more precise, for a bourgeois enterprise, the 'absolute limit of exploitation' is constituted by the average profi $t$ of capital; for the small-commodity producer who sells the whole of his output, the limit is set by the costs of simple reproduction, comprising mainly his 'wage'. In the medieval world, as feudal consumption became bound up with the expanding currents of circulation and implied progressively higher levels of monetary expenditure, a specifically feudal structure of accounting tended to crystallise: 'costs' were defined mainly as those items of expenditure which required an outlay of cash, and 'profits' as all items of monetary receipt. As items of expenditure, the elements of consumption and production were merged into a common category, something like the 'sum of all expenses', which was then deducted from receipts to obtain an apparently spurious 'net balance'. ${ }^{106}$ This ratio of receipts to expenditure was calculated as the ratio of two consolidated sums; even when, on the side of income, the proceeds from the sale of various crops figured as separate items of receipt, costs of production were distributed under various agricultural operations, so that no attempt was made to determine individual monetary costs of production, or even the monetary costs of crop production as a whole. As all items of cash-income were regarded as 'profits', independently of any mechanism of cost-calculation, crops were more or less 'profitable', not according to their monetary rate of profit but according to the volume of cash which they brought in. ${ }^{109}$ Any increment in crop-production which increased the total volume of these receipts, however marginal its contribution, was therefore 'profitable'. That is to say, for a given distribution of productive forces, even if it made sense to sell a given output at the highest price, sales would nonetheless continue over a wide range of prices below this bound. In short, in an economy which dissociated production from the 'rational' calculation of costs and which regarded 'profits' not as a ratio but as a simple magnitude, the 'limit of exploitation' could only be a vague and elastic concept, and one which could assert itself only in the longer run in a sort of feudal 'scissor's crisis', as the hiatus between income and consumption widened over a number of years.

(ii) Once the estates established a certain connection with the market, the lord's income became a function of three variables: (a) the volume of gross output, which would tend to fluctuate sharply from one year to the next; (b) the coefficient of the marketable surplus, whose elasticity would vary more or less directly in proportion to gross output; (c) the current price of grain..$^{10}$ As no estate had any control over prices, an expansion of manorial incomes depended mainly on expanding the marketable surplus. As the level of internal 
consumption was more-or-less constant, the volume of this surplus, sold on the market, would vary proportionately to the volume of the harvest. At the existing level of technique, the average productivity over time was a function of the surface in production and therefore of the disposable mass of labour-time. It follows that, in these conditions, the 'maximisation' of feudal profits necessarily implied incursions into the sector of small-peasant production, from which the estates drew their sources of labour.

\subsubsection{Peculiarities of the 'second serfdom'}

The feudal mode of production prevailed in England, for example, in its period of 'high farming' c. 1230, as well as in Poland c. 1600, when most of Western Europe was becoming heavily dependent on Polish grain exports. In England in that period, as in Poland, the larger and better-organised estates were extensively involved in the production of grain for the market, selling up to $80 \%$ of net output. But a deeper comparison would reveal differences of some interest. Of England, we are told by Duby,

to associate the tenants with the labour of the demesne in the thirteenth century was an anachronism... The revival of forced labour seems, therefore, to have been very limited: it was only temporary, since it declined definitely on the monastic estates after 1275, and was restricted in scope, since labor services were only used to reinforce those of manorial employees."11

Seventeenth-century Poland, on the other hand, was experiencing a substantial feudal offensive, with the nobility beginning to 'limit the area of their peasant's cultivation, and, in this way, enlarge their own land' ${ }^{112}$ If we take these cases as prototypes of the fi rst and second serfdoms respectively, it is clear that the tendency of demesne-consolidation at the cost of peasant-production, which they both reveal, prevailed with varying degrees of intensity in these conjunctures. The extent to which it prevailed and the intensity of its effects were a function of broader economic factors. The possibility of expanding manorial incomes or safeguarding feudal consumption by means other than direct management depended mainly on the elasticity of the surplus in smallpeasant production, while demesne farming could itself be organised mainly on the basis of paid labour. At any rate, whether estates converted to monetary payments or retained demesne-cultivation with the use of paid labour, both processes posited a certain level of currency-circulation. At a deeper level of analysis, therefore, the first significant contrast between the epoch of 'high farming' and the 'second serfdom', between the two extremities of Europe, is located here. In the West, the enormously expanding weight of the seigneurie banale on which Duby lays so much stress in his most recent work, ${ }^{113}$ and the growing volume of monetary payments by the peasantry implied proportionate increases both in the stock of money and in the velocity of its circulation. The leasing of demesne-lands, the imposition of jurisdictional taxes, entryfi nes and 'permanent rents', the movement of commutation and the growing volume of peasant-indebtedness - all cash-transactions or transactions based mainly on cash - make no sense on any other assumption. In relative terms, the level of currency-circulation was quite different in the East: in Poland, it actually diminished in the early part of the seventeenth century, compelling 
the nobility to adapt to this situation by intensifying the economic isolation of the estate and establishing in this way, as Kula remarks, a 'mechanism of closed monetary operations' ${ }^{114}$ In the second place, conversion to monetary payments required a peasantry capable of producing for the market; and these surpluses would tend to derive mainly from the more substantial households. Although, in the West, the expanding weight of population after the early phases of arable colonisation led into a spontaneous fragmentation of most peasant manses, both the gradual improvements in productivity and the relaxation of feudal pressures on the peasant's surplus had enabled this sort of peasantry to establish itself. Once the structure of feudal exploitation itself became more diversified and fluid, this sector of the peasantry, the real base of peasant commodity-production in the feudal social formations, could consolidate its position to an even greater extent. In the East, the whole process of differentiation was more or less repressed up until the nineteenth century. The peasants' share of the total volume of grain-sales was therefore never very significant - in late tsarist Russia, landlords accounted for $90 \%$ of the marketed output of grain, and the eventual conversion to monetary payments (obrok in the Russian countryside) required migrations of the peasantry in search of employment [otchod]. ${ }^{115}$ Finally, the momentary vigour of demesne-farming in England was supported by an extensive use of hired labour and consequently closely linked to the overpopulation of the English countryside. Earlier conditions connected with clearance-operations and the expansion of arable - viz. improvements in agricultural techniques; gradual increases in productivity; the shift to a grain-centred system of husbandry and the connected shifts in the peasant's diet; the conversion of slave-gangs into serf-households - all favoured a rapid growth of the serf-population. By the middle of the thirteenth century, as this movement of grain expansion came to a halt, a new phase of 'overpopulation' was becoming evident. ${ }^{116}$ In England, the proportion of serf-households which at that time was living at or even substantially below subsistence was close to $80 \%$. The emergence in these conditions of a village-proletariat expanded the supply of labour at a subsistence wage, promoted the use of such labour on the medium and small estates insufficiently provided with villeins, and attracted even the bigger estates by its greater seasonal flexibility. About a third of the English peasant-population worked for wages in this period. ${ }^{117}$ This increasing use of paid labour was closely linked with the expansion of monetary payments and with expanding levels of currency-circulation. By contrast, in Poland, Ukraine, Lithuania, the low level of currency-circulation and the high level of wages made an extensive use of such labour practically impossible. Unlike the lower layers of the nobility in England, who depended largely on reserves of free labour, the smaller Russian landowners, the svoezemtsi, who were their counterparts, were compelled to work their own lands, aided by slaves. ${ }^{118}$ 'The Russian landowners', wrote Marx, 'complain about two things: first, about the lack of money-capital...The second complaint is more characteristic. It is to the effect that even if one has money, not enough labourers are to be had at any time'. ${ }^{119}$

In short, a dearth of cash, a more backward differentiation of the peasantry, and a scarcity of free labour were the basic conditions distinguishing the 'second 
serfdom' from the so-called 'classical' feudalism of the medieval West. 2.6.3. Commodity-feudalism as the pure form

The greater intensity and more primitive character of the 'second serfdom' were thus closely conditioned by the real rhythms of economic activity implicit in the movement of population and currency. But this greater primitiveness should not be confused with a more backward development of feudal production. In this primitiveness of the 'second serfdom' we find, in fact, an important clue to the real logic of the feudal enterprise. In the West, which is generally characterised as the locus of a 'classical' feudalism, the estate attained its really classical structure, as defined earlier (Section 6.1), only sporadically, and then mainly in the period of 'high farming';

that is, as a temporary and even abrupt prelude to the long process of diversification

which followed towards the close of the thirteenth century. Surveying the development of the feudal economy across the whole of this early epoch, it is undeniable that, as feudal enterprises, the estates in the medieval West possessed a far more fl uid and diversifi ed structure than those which sustained the second serfdom. There, labour-services were for at least two centuries (centuries central to the epoch of 'classical' feudalism), a less powerful pressure on the peasant's labour-time than the seigneurie banale, as Duby argues.

Even in the brief outburst of high farming, when the estates turned to commodityproduction and attempted to compress the sector of small-peasant production into totally subordinate reserves of serf-labour, the largest and best-organised estates, such as those of the Bishop of Winchester, continued to derive a major share of their income from more archaic monetary payments and from marriage and entry-fines. Thus, the form of organisation of labour based on the partial autonomy of small-peasant production persisted even in this phase of intensifi ed labour-services. By contrast, in the central period of East-European feudalism, this distinction of forms was of practically no significance: the large mass of the peasantry were reduced to the position of 'serfs', i.e. bound by labour-services; and the character of feudal enterprise in these countries was typically far less fl uid, far more bound up with the exploitation of 'serfs' than in the West some centuries earlier. In other words, the feudal enterprise in the early epoch of so-called 'classical' feudalism crystallised, or acquired its truly classical form (with the labour process reducing the sector of peasant-production to a reserve of simple reproduction), only sporadically; and then only rarely in its pure form. In the grain-exporting countries of the 'second serfdom', the predominant form of feudal enterprise was the developed form. The primitiveness and barbarity of their social relations were an expression of the maturity of feudal relations of production, of their relative purity.

The clue to this contrast lies in the origins of the 'second serfdom'. When the countries of Eastern Europe plunged into this epoch, a world-market was already in the process of formation. Merchant-capital had already established an important and expanding grain-trade, which, in the course of the fourteenth century, was progressively integrating the Baltic into a European division of labour. 
Marx himself, and most later Marxists, assumed as a matter of course that 'feudalism' evolved by a simple progression from labour-services to monetary payments through an intermediate form of 'rent in kind'. But if, in order to explain the peculiar connection between the purity of the 'second serfdom' and its location in an emerging world-market, we return to the early patriarchal Europe of the Carolingian period, we find that labour-services were of practically no importance on the manors of Gaul, Germany, Flanders and Lombardy: in this vast region of early feudal Europe, the demesne utilised slave-labour, and the peasantry were exploited through payments in kind. ${ }^{100}$ In a famous article, Kosminsky set out to show that the monetary payments which predominated in England much later were only partly the result of commutation, and that a certain proportion of these payments derived from a more archaic structure of money-rents. ${ }^{121}$ In the debate on the 'transition', to make the point that market-relations did not accelerate the decay of forced labour in England, Dobb cited this article by Kosminsky; he argued that serfdom (labour-services) disappeared 'earliest' in the backward and commerciallyremote regions of the north and west. But Kosminsky's thesis was different: in these backward regions, labour-services had probably never prevailed. Thus, both in England and on the Continent, there were substantial zones where labour-services had been of little importance originally, and where payments assumed the form of produce or money. In Kosminsky's terms, the structure of the manor evolved independently of any formative infl uence of payments in labour.

Eastern Europe, in its own phase of backward patriarchal isolation, provides even clearer evidence. In Hungary, in the fifteenth century, the peasantry was exploited predominantly in the form of money-rents and produce-rents; Pach notes that a demesne-economy as such had barely developed at this stage..$^{12}$ Around this period, in Mecklenburg, Prussia, Bohemia, Poland and Russia feudal incomes derived, as in Hungary, mainly in the form of cash- and kind payments..$^{123}$

The significance of this fact is enormous. It suggests that not only did the crystallisation of feudal relations of production find its only true and widespread expression in the 'second serfdom' (i.e. the more backward eastern periphery of Europe); but the feudal estate only crystallised (i.e., acquired its developed, 'adequate' form) not in the relative isolation of a Europe cut off from markets and forced to depend on local production, but precisely when the estate itself assumed the character of a commodity-producing enterprise. Labour-services, Kosminsky had argued, were more strongly represented in the most populated and industrialised areas with the biggest markets. ${ }^{124}$ That is to say, insofar as the feudal enterprise tended to crystallise in its pure form in the earlier epoch of feudalism, the context was an expanding market. The history of the 'second serfdom' substantiates this point, if only because the process of crystallisation here was neither held back nor obscured by the survival of a specifically small-peasant production, and by the correspondingly more fl uid nature of the enterprise. As the countries of Eastern Europe were drawn into production for the emerging world-market or for an expanding domestic market (which was the case in Hungary), labour-services advanced 
rapidly against both earlier forms of payment. This type of exploitation was thus a later development, and it reached its maximum intensity in agricultural regions close to urban centres, (for example, the zones surrounding Moscow and St. Petersburg), or in the hinterland of the port cities and major trade-routes. ${ }^{125}$ The chronological distribution of labour-services shows the same pattern. In the second half of the sixteenth century - to cite only one example - as cereal-prices in the port of Danzig increased on average by some $200 \%$ over fifty years under the pressure of expanding exports, the volume of labour-time mobilised from a full-sized peasant-holding on the estates increased by over $400 \%$. Every favourable price conjuncture intensifi ed the drive to expand the demesne at the cost of small-peasant production and to increase the volume of disposable serf labour-time both directly by imposing heavier work obligations and indirectly by a policy of cutting the size of the peasant-plot. The process of evolution of the classical manor, which the countries of the West, in particular England, had experienced in a relatively mild and impure form, was destined to be repeated at higher levels of intensity, without the same impurities, in Prussia, Denmark, Poland and Hungary ${ }^{; 16}$ and, finally, Russia, in the period inaugurated by the 'revolution of the world market' in the sixteenth century. Under the impact of successive commercial booms, the European dimensions of which were already evident as early as the fourteenth century, ${ }^{17}$ the estates, formerly relying on produce in kind or, to a limited extent, rents in cash, converted small-peasant production into a reserve of simple reproduction: a process described by Pokrovsky as the serfowner's leap into 'new and more complicated forms of production'. ${ }^{128}$

But this process was not peculiar to the countries of Eastern Europe: it had been known much earlier, not only, on a limited scale, in the West, but also in China; and was found at that time and later in the major countries of colonial Latin America. We know that in the major countries of Latin America the form which the feudal estate assumed was the hacienda. The hacienda was an enterprise 'always dependent on a fairly large market for its products'. ${ }^{129}$ Both major phases of expansion of the hacienda in Chile, for example, coincided and were closely tied up with the expansion of demand for Chilean grain. The hacendado could expand his volume of sales in such periods only by transforming peasant production into feudally-subjugated simple reproduction. In the course of successive booms, the older arrendatario gradually disappeared from the countryside of central Chile, replaced by a new serf-population of inquilinos concentrated in the areas which produced for the wheat-market. Peasantlivestock rapidly disintegrated in this process, peasant-holdings degenerated into subsistence-plots, and the earlier more deeply differentiated structure of the peasant-population, separating more prosperous tenant-households from the remainder, collapsed into a more or less uniformly impoverished mass. ${ }^{30}$ In China, the same tendencies are evident some ten centuries earlier. Here, already in the T'ang epoch, the big estate had become a common feature of rural economy; but, in that period, before the commercial boom of the eleventh century, the tenants [tien-hu] who worked these estates under the control of bailiffs were generally bound by payments in kind, equivalent to half the 
crop. On the Sung estates, especially those of the prosperous coastal provinces of the south where 'wheat was grown purely as a cash-crop for sale in the cities of the lower Yangtze area', ${ }^{131}$ the same tenants were progressively bound by labour-services and their mobility restricted in law. A substantial number of Sung estates worked by these serf-households 'produced either regularly or intermittently for the market'.132 The parallel between the condition of such Sung peasants and the serf-populations of Europe was suffi ciently striking to make the Japanese Marxist historians who pioneered Sung economic history date the transition to feudalism in China precisely at this conjuncture, when the whole southern economy was transformed by the rapid growth of cities, expanding levels of monetary circulation, a vast boom in the grain-trade and the establishment of commercial links with Europe through the intermediary of Arab traders.

To summarise; we defined the classical or developed form of the feudal enterprise as one which necessarily implies the lord's complete control over the labour-process; that is, where small-peasant production no longer retains its former autonomy but now functions in the form of a sector of simple reproduction, sustaining surplus-production on the demesne. We argued that, both in Europe, and elsewhere through the vast epoch of feudal production, the estate acquired this developed structure only as a commodity-producing enterprise. When Frank witnessed the signs of this specifi c evolution in the colonial history of Latin America, where it was repeated in a defi nite series of cycles, he could understand it only by reconstructing the hacienda in the image of capital; thus entirely ignoring the specific laws of motion according to which such enterprises operated; laws deriving not from the compulsion to accumulate, but from the compulsion to defend and improve social-consumption levels which rapidly lost their patriarchal (non-monetary) character, if they had had such a character to begin with. But, when Frank's critics quickly demolished this illusion, the formal-abstract premises from which they started led them to the conclusion that, 'on the contrary', the market was a factor of feudal 'consolidation'. This poses a final question, namely, the 'long duration' of this type of economy, or the problem of its decline.

\subsubsection{Modes of production as objects of long duration}

The 'long duration' is the least perceptible, and in a sense, the slowest of all forms of historical time. Its effectivity is staggered across centuries, and its reality only measurable on that scale. Insofar as Marx conceived of modes of production in a broader, more truly historical sense as 'epochs of production' or 'epochs in the economic development of society', he implied that they were objects of this order of magnitude.

Pirenne had argued that as commerce and the stock of money expanded, the old economy of subsistence and custom could no longer adjust to the new and more sophisticated levels of consumption; the nobles were forced to borrow and their régime disintegrated. Even earlier than Pirenne, Weber had posed the question in similar terms; for him, the 'immediate cause' of the breakdown of the 'manorial system' had been the development of market-operations and 
market-interests on the part of both lords and peasants, although the major impetus derived, in his view, from the nascent commercial bourgeoisie of the towns who promoted the dissolution of the manor because 'it limited their own market opportunities' ${ }^{133}$ As a collapse-theory, the Pirenne-Weber thesis was obviously wrong: over short conjunctures, most estates were clearly capable of adapting to the market and expanding incomes. ${ }^{134}$ Expanding levels of demand and the growing weight of monetised consumption could be sustained over a cycle of short conjunctures by stepping up the rate of jurisdictional income; intensifying demesne-exploitation; substituting short-term leases or exacting entry-fines to siphon off the cash-holdings of more substantial peasants or to profit directly from inflation. Impressed by these short conjunctures in which the best estates in particular demonstrated their ability to prosper, Dobb concluded that the market was a factor of consolidation, and that the decline of feudalism lay 'within' the 'sphere' of production, in the static levels of labour-productivity which would eventually compel the lords to overexploit their serfs and reduce their rates of reproduction. ${ }^{135}$ Neither Dobb nor Sweezy saw that, to make any sense at all, their respective 'theories' of feudal decline posited each other; and neither posed the question of the durational scale over which each position could hold true when integrated with the other. The 'market' and the 'overexploitation of serf-labour' were not relatively independent phenomena, or factors which simply 'interacted', as both Dobb and Sweezy conceded in their moments of generosity. They were indissolubly linked aspects of a single process, the 'long duration' of feudal production.

In large areas of Europe, and outside Europe, the feudal estate acquired its classical or developed form only as a commodity-producing enterprise. In countries such as Hungary, Poland, Russia, and later in certain parts of the colonial world, the expansion of a demesne-economy and labour-services which had formerly been of little or no signifi cance, began directly with and under the pressure of an expanding demand for agricultural produce in local and international markets. This adjustment to the market suited both the serfowners

and the importers of grain. It suited the latter because, in the feudal economies, there was no specifi c limit of exploitation which posited a certain level of prices. The fact that any sale brought a 'profit' and the perpetual thirst for such 'profits', ensured an abundant supply of grain at low prices. The adjustment suited the serfowners because the expansion of the market itself implied higher levels of monetised feudal consumption. As feudal consumption inevitably lost its patriarchal character; as the lure of old models of consumption ceased or the civilising infl uences of an established nobility exerted a pressure of sophistication on the consumption-needs of cruder barbarian aristocracies; and as the monetary share of feudal consumption progressively expanded to a point where 'internal consumption' was of scarcely any importance - the thirst for cash became the dominant motive force of feudal production.

This 'thirst for cash' in fact operated in all but the patriarchal periods of 
medieval history; those exceptional conjunctures where trade declined, towns reverted to villages, and consumption was predominantly of a natural character. Once a network of world commodity-exchanges was established, it became an even more pervasive, more powerful factor. Driven by this thirst for cash, which each fall in the value of currency intensified enormously, the nobility reacted to the market in two distinct phases. Initially, the slowly rising levels of grain-prices would have automatically adjusted the rate of exploitation in the peasants' favour, if, as was normally the case, the level of monetary payments which prevailed earlier tended to remain static. In this phase of slow infl ation, the lord's first response would be a progressive readjustment of the level of payments to the level of prices. This was, for example, the initial reaction of most Russian landlords during the sixteenth century, when the Polish nobility not far away was already constructing the foundations of a demesneeconomy.

In Russia, 'the increase in cash obrok during this century just about kept pace with the fall in the purchasing power of the currency' ${ }^{136}$ But, even in these phases of a gradual upward movement of prices, there were more far-sighted serf-owners who, to preserve the level of their income, turned to production for the market. Feudal commodity-production might originate then as a purely defensive manoeuvre, as in England, where 'in the face of the tendency for prices to rise, a more or less static income encouraged borrowing in order to sustain a customary level of consumption...The abandonment of leasing might be a step towards solvency and a means of safeguarding consumption standards'. ${ }^{137}$ Then, as the infl ation periodically accelerated, more and more estates would be drawn into production for the market; and this compulsion would be so much stronger where feudal rates of consumption, now expanding more quickly in money-terms, pushed against the limits of a low elasticity of surplus in peasant-production and a low velocity of circulation in local markets.

Under the pressure of successive infl ationary conjunctures of this type, a new and distinct phase of feudal production would begin, a phase of crystallisation, with demesne-arable expanding by incursions into fallow, forests, pasture and grazing land. At low and generally static levels of productivity, output was limited mainly by the extent of arable in cultivation; and the expansion of arable required a proportionate expansion of the disposable mass of labour-time. The construction of demesne-economy, the process through which the feudal enterprise acquired its adequate form, implied a series of sharp and brutal inroads into peasant-land and a vast project of mobilising labour-power from the surrounding villages. This unwritten history of the 'primitive accumulation' of feudal economy evokes its most striking expression in the 'second serfdom', only because in the countries of Eastern Europe and the Baltic, the relatively sudden nature of their integration into the emerging world-economy compacted the process into a matter of decades. Where labour-services had existed formerly, their specifi cally low weight, at most one day per week, implied a basic compatibility with small-scale production. In the phase of crystallisation, with the weight of these services rising by several hundred per cent over a few decades, small-peasant production would be 
more or loss rapidly converted into pockets of simple reproduction. The division between the peasant's necessary and surplus labour-time would now be directly encapsulated in the distribution of arable, with the peasant's holding fl uctuating around the limits of subsistence.

Within the framework of this classical feudal economy with its specifi cally feudal organisation of the labour-process, the basic obsession of estate-management remained as before the adjustment of rates of income to rates of consumption, but now magnifi ed on the larger scale of a more labile monetary consumption. Where consumption had retained its patriarchal character, the rate of feudal income would have fl uctuated sharply from one year to the next because the level of technique was never suffi ciently high to dominate and control the stochastic cycle of production. To overcome potentially vast disproportions, the productive capacity of the undeveloped patriarchal estate would have been organised to ensure outputs above the level of current (internal) consumption. Once the circulation of money impinged on the organisation of this patriarchal economy, the curve of the new monetised feudal consumption would show a slow upward trend punctuated by short spasms of expansion with every fall in currency-values. But with income dependent on commercial surpluses and computed as the product of price and output, the inverse movements of these variables such as characterised feudal conditions would tend to average out the rate of revenue from year to year. ${ }^{138}$ As the rate of productivity tended to constancy, prices were given exogenously and rates of consumption were infl exible downwards, the estate could respond to this growing crisis of profi tability by heavy borrowings, by the liquidation of assets, or by increasing the volume of output, hence the surface in production and the mass of available labour-time. Yet each of these responses expressed tendencies of feudal disintegration, and the later they supervened in the long cycle of feudal-commodity economy, the more sharply were these tendencies revealed. When the consumption of the serfs already oscillated around a level of simple reproduction, that is, when the classical form of the feudal enterprise had already crystallised, every new drive to 'maximise sales' - that is, to push the level of serf-consumption below the existing limits of simple reproduction - would in the longer run radically shorten the periodicity of the old crises of subsistence and aggravate their intensity; it would thus depress the rate of reproduction of the serf-population to one degree or another. ${ }^{139}$ The progressive indebtedness and bankruptcy of the lords, the liquidation and ever increasing mobility of feudal property (comprising, as one of its elements, the serf-population itself), the compulsion to expand the volume of output or to expand the fi eld of feudal colonisation and the ever greater frequency of short-term subsistence-crises were basic long run tendencies of feudal production, the necessary expression of its specific laws of motion, present to one degree or another in all sectors of the feudal world. ${ }^{40}$

In this sketch of the long duration, it is impossible to produce an abstract separation between the 'market' and the 'process of production' as if these were 'factors' of decline. The inherent limits of the 'process of production' on which Dobb focussed in the debate were only revealed, i.e. only became effective as limits, in the context of expanding commodity-production or its underlying 
thirst for cash. Moreover, if, as Sweezy argued, the market was a factor of feudal disintegration, it could become so on the basis of the specifi c laws of motion of feudal economy, and only in the long run. In this sense, the debate argued from false premises, because the question which it posed posited a 'process of production' divorced from the specific character of feudal consumption, and a process of exchange devoid of any compulsion to exchange.

\subsubsection{Two brief conclusions}

To relate this short discussion more closely to the themes mentioned earlier:

(i) Although it is in some sense quite self-evident and banal, the distinction between 'modes of production' and 'social formations' that is generally drawn in most recent Marxist literature may actually obscure and mystify the mechanisms of modes of production. For it is a fact that, even in its crystallised form, the feudal enterprise was sustained by a variety of forms of labour; comprising domestic servants who were legally slaves and who often undertook the principal tasks, especially ploughing, day-labourers who were housed separately on the estate; part-time hired workers recruited from the impoverished peasantry, free tenants who performed seasonal or supplementary services; and the serf-population as normally understood, i.e. villeins bound by labour-services. The slaves and hired labourers who intervened in this type of economy were as much part of specifi cally feudal relations of production as the serf-population itself. Their intervention did not signify the persistence or emergence of other relations of production ('slavery'; capitalism), and did not therefore imply an 'articulation' of several distinct 'modes of production'. Consistent with the logic of his defi nitions, Dobb was, however, forced to argue on these lines; the fact, that, on the thirteenth-century English estates which turned to commodity-production, the lords made increasing use of hired labour, signified for him the emergence of a 'new', i.e., capitalist, mode of production. If Dobb had really believed this, the debate on the transition would have had to deal with a second problem: not only the decline of feudal economy, but the decline, in fact collapse, of the barely established capitalist one. For as we know, this phase of commodity-production with hired labour was rapidly superseded in the history of Western Europe; and, as Dobb himself argued, the feudal enterprise preserved its dominance, in progressively modifi ed forms, for at least another two centuries. Relations of exploitation based on the dispossession of labour, on the commodity labour power, become capitalist relations of production only when we can posit the capitalist enterprise in one of its varied forms. Marx makes the point indirectly when he writes: 'if a nobleman brings the free worker together with his serfs, even if he re-sells a part of the worker's product, and the free worker thus creates value for him, then this exchange takes place only ... for the sake of superfluity, for luxury consumption' ${ }^{\text {in }}$ In other words, hired labour functions in this economy as an expression of specifically feudal relations of production, the motive-force of which lies in the social-consumption needs of the owners of the feudal enterprise; it functions in an economy in which the production of commodities is itself only a mediation of consumption. (ii) The idea of world-economy as already dominated from its inception by the requirements of capital-reproduction is a false abstraction. To put the argument in its crudest form: the initial impulse which sustained the vast network 
of world commodity-exchanges before the eighteenth century derived from the expanding consumption-requirements of the lords. Moreover, at its inception the colonisation of Latin America was a feudal colonisation, a response to the crisis of feudal profi tability which all the landowning classes of Europe were facing down to the latter part of the sixteenth century. In the Baltic and Eastern Europe, this crisis was partly overcome by territorial expansion into contiguous areas, and then displaced by the production of grain for export; but, in the maritime periphery of Europe, in Spain and Portugal where this feudal crisis recurred with periodic sharpness, it expressed itself in a movement of overseas-colonisation. The Spain which launched this movement of expansion was a Spain dominated by feudalism, but a feudalism in crisis. This thesis is not, of course, new: it was proposed by Vilar many years ago, when he described Spanish imperialism as the highest stage of feudalism; ;12 and intimated some years later by Marian Małowist, when he asked whether the Spanish colonisation was not, to a certain extent, "the result of a depression in rural economy and a sudden drop in the revenues of the nobility'. ${ }^{133}$ The forms which this widespread feudal crisis took in different sectors of Europe, its specifi c local intensity, and the means used to overcome it are matters for investigation by historians. Suffice it to say that the crisis of feudal profi tability not only unleashed movements of internal colonisation in Europe itself, in the land-locked territories; but the fi rst major 'imperialist' conquest; and, if we examine the question more closely, those bastardised forms of capitalist production which prevailed in the colonial plantations, the profi ts from which enabled many bankrupt noble families to re-establish their economic position.

\subsection{Simple-commodity production: a 'determination of form'}

2.7.1. The peasant mode of production

The historical roots of all varied forms of simple-commodity production lie in the patriarchal-subsistence mode of production based on small-scale parcellised property and the exploitation of family-labour. ${ }^{14}$ This connection is

important because when simple-commodity production arises, the economic logic of the more archaic patriarchal enterprise continues to dominate this form of production. The chief expression of this fact is that products are sold without regard to price of production. According to Marx,

[The small peasant operating in this mode] regards the expenditure of labour as the indispensable prerequisite for the labour-product, which is the thing that interests him above all. But, as regards his surplus-labour, after deducting the necessary labour, it is evidently realized in the surplus product; and as soon as he can sell the latter or use it for himself, he looks upon it as something that cost him nothing, because it cost him no materialized labor...Even a sale below value and the capitalist price of production still appears to him as profit. ${ }^{145}$

It follows that 'for the peasant owning a parcel, the limit of exploitation is not set by the average profit of capital...The absolute limit for him...is no more than the wages he pays to himself, after deducting his actual costs. So long as the price of the product covers these wages, he will cultivate his land, and often at wages down to a physical minimum'. ${ }^{146}$ 'It is not necessary, therefore, that the market price rise either up to the value or the price of production 
of his product. This is one of the reasons why grain prices are lower in countries with predominant small peasant landownership than in countries with a capitalist mode of production' ${ }^{147}$ In Kautsky's conception, based on these passages of Marx, this 'incomplete remuneration for the labour-power expended' was, as Lenin notes, 'the distinguishing feature of small production'. 'As long as the peasant remains a simple commodity producer, he can be satisfi ed with the standard of living of the wage-worker; he needs neither profi t nor rent; he can pay a higher price for land than the capitalist entrepreneur' ${ }^{\prime 48}$ In short, simple-commodity production internalises the patriarchal logic of the subsistence mode of production, much as feudalism does in its own way. Outputs are sold as a function of subsistence, and dissociated from any mechanism of 'rational' cost-calculation. In this devalorisation of labour-time lies the specifi c advantage of all small-scale forms of production threatened with extinction by the capitalistically produced commodity. In the epoch of capitalism, as Kautsky argued in Die Agrarfrage, 'overwork' and 'underconsumption' become the twin slogans of the peasant-economy.

\subsubsection{The simple-commodity producer as wage-slave}

As a pure form, simple-commodity production is a form of economy of a purely subordinate and transitional character, in which: (i) the labour-process preserves its patriarchal character, with the predominance of the self-suffi cient peasant family-labour farm as the basic enterprise of production. (ii) The producing households preserve not only their self-sufficiency, transforming only their surplus into commodities, ${ }^{149}$ but their independence as the basic agents of the productive process, chiefl y expressed in their freedom to allocate labour-time between commercial production and immediate consumption, and between the different types of commercial production. (iii) The system of accounting retains a specifically patriarchal, subsistence-based interpretation of 'costs' and 'profits', as noted above; here the 'limit of exploitation' is equal, in principle, to the costs of simple reproduction. (iv) Subsistence remains the goal of production, even in those limiting cases where the whole of household labour-time is absorbed in commercial production. (v) As the co-efficient of marketed output rises and the monetary components of the labour-income expand, the volume of sales will tend to vary inversely with the movement of prices (the 'backward-sloping supply-curve' thus typically characterises households in this position). (vi) Fluctuations of the market introduce a process of differentiation among simple-commodity producers, which, in the fi rst instance, remains a differentiation of wealth, i.e. preserving its historical content as a differentiation of simple-commodity producers. ${ }^{150}$

As Marx and Lenin were aware, the subordination of the simple-commodity mode of production to the power of capital converts this mode into the embryonic basis of specifi cally capitalist production, but a capitalist production which retains the determinate organisation of labour specifi c to the 'precapitalist' enterprise. Marx describes this process perhaps more rigorously in the following passage than anywhere else:

[The] exchange of equivalents proceeds; it is only the surface layer of a production which rests on the appropriation of alien labour without exchange, but with the semblance of exchange. This system of exchange rests on capital 
as its foundation, and, when it is regarded in isolation from capital, as it appears on the surface, as an independent system, then it is a mere illusion, but a necessary illusion. ${ }^{15}$

Let us examine this process more closely.

The subjugation of the simple-commodity form of production to capital proceeds inevitably within the limits imposed by the prevailing organisation of production. Capital's struggle to dominate the enterprise of simple-commodity producers - to determine the type, quality and volume of its commercial output - posits as its basis the limitations imposed on its own elasticity by a labour-process not determined by itself; in which, therefore the enterprise of small producers retains its independence, if only as a formal determination ('quasi-independence'). ${ }^{\text {s2 }}$ Domination over the labour-process becomes impossible on this basis, within these limits of quasi-independence, without those mechanisms which uproot the patriarchal suffi ciency of the small enterprise. The compulsory enforced destruction of the small producer's selfsufficiency figures here as the necessary foundations for the dominance of capital. ${ }^{153}$

It follows that in this articulation, except at the limit where the enterprise effectively ceases to exist, where its formal independence is converted into the complete dependence of free labour on capital, the capitalist's control over the labour-process retains a partial and sporadic character. Frequent adulterations of the crop, as with the cotton produced in western India in the 1860s; smuggling on the open market, as with poppy grown in Bengal much earlier; restrictions in the volume of output, such as the colonial bureaucracies persistently feared; and the switching to more 'profitable' cash-crops, reflect this partial and unstable character of the capitalist's control.

Yet, within the limits of such control, continually re-established on the basis of various coercive forms of exploitation, the relations of production which tie the enterprise of small-commodity producers to capital are already relations of capitalist production. Between the market and the small producer, capital intervenes with the determinate forms and specific functions of both merchant and industrial capital (as in the slave-plantations, two radically distinct 'determinate forms' merge). In this process, two enterprises are thus present, a quasi-mercantile capitalist enterprise, ${ }^{\text {si }}$ which figures solely as a unit of production (as defined earlier) without the labour-process specifi c to its mode of production; and an enterprise of formally independent small producers functioning according to its own labour-process, inherited from the conditions of a patriarchal economy, and according to its own economic conceptions, also patriarchal in their determination, but no longer as a totally independent unit of production. The social process of production incorporating the immediate labour-process of the small-peasant enterprise is governed by the aims of capitalist production; namely, by the compulsion to produce surplus-value. Within this social process of production dominated by the capitalist enterprise, the economic conceptions of the small households, and their formal possession of a portion of the means of subsistence, enter as regulating elements only as a function of the law of surplus-value production. The patriarchal notions of 
accounting, which dissociate the range of acceptable market-prices from the price of production and the autonomous internally subsidised reproduction of labour-power which from the perspective of the process as a whole, ensures a sale of labour-power below its value, enable capital to depress wages 'in a fashion unequalled elsewhere', as Engels noted. ${ }^{\text {.s5 }}$

When we regard the simple-commodity enterprise articulated to capital, no longer as an independent unit of production imposing its own laws of motion on the process of production, but as a quasi-enterprise with the specifi c social function of wage-labour (in the strict sense, value-producing labour); in other words, when following Marx's method, we have correctly 'determined its form', ${ }^{156}$ some conclusions are immediately evident. In the first place, the 'price' which the producer receives is no longer a pure category of exchange, but a category, that is, a relation, of production, a concealed wage. Behind the superfi cial 'surface' sale of products, peasants under this form of domination sell their labour-power. Secondly, the monopsonistic determination of 'prices' under this system, or the fact that the contracts which fi $x$ this price may often also stipulate the volume of output required and its specific quality, are necessary expressions of the capitalist's 'command over labour power' ${ }^{157}$ The more perceptive colonial administrators regarded such contracts 'as of the same kind as one between a capitalist and a worker' ${ }^{\prime}{ }^{158}$

Finally, subsistence-production now figures, under this system, as the specific form of reproduction of labour-power within a capitalist process of production. It becomes misleading, therefore, to regard it as a specific, separate mode of production (e.g., a 'domestic mode of production') in a system of modes of production dominated by capitalism. This was, after all, the illusion which Lenin polemicised against so vigorously in his earlier writings against Narodnism, repeatedly making the point that capitalism always takes the 'technical process of production' as it finds it. Yet this illusion is today widespread in the neopopulist currents of 'Third-World political economy' which paradoxically end up by reconstituting the thesis of 'dual economy' at the very centre of their analyses, now in a Marxist terminology and with slight modifi cations of the original premises. ${ }^{159}$

In the colonial period, capitalistically-subjugated simple-commodity production, or, more precisely, capitalist production which is mediated through an internalised 'simple-commodity producing' enterprise, accounted for a major share of colonial output, when the latter did not derive from commodityfeudal estates or capitalist slave-plantations. The entire economy of certain sectors of the colonial world - West Africa, Uganda, Mozambique, Bengal, Burma, Cambodia - was dominated by this backward form of capitalist production at its various stages of crystallisation. .60 $^{160}$ In one of his very last references to colonial questions, Marx wrote that, with their integration into the world-economy, the earlier forms of production which had prevailed in India, China, Egypt disintegrated but that this process of disintegration was not initially 'apparent' ${ }^{161}$ The colonial peasants integrated into commodity production 
by a process called 'forced commercialisation' entered capitalist relations of production behind the backs of their existing forms of production: here, capitalist production thus retained a 'surface layer', an 'appearance' of superseded forms of economy, the peasants 'retained the external attributes of independent producers', ${ }^{122}$ and the forms of reproduction of labour-power retained the appearance of distinct, even if 'dependent', forms of production.

Thus, late nineteenth-century colonialism acquired a paradoxical character. In the midst of societies of apparently 'ageless stagnation', those that Marx called 'peasant nations', ${ }^{163}$ a form of capitalistic production had already begun to establish a fairly deep local penetration. The capitalism that evolved on the foundations of small-commodity production differed from the classical or adequate form of capitalist production in several fundamental ways. In the industrialising sectors of the world-economy, the rule of capital depended crucially on the dispossession of labour from all means of subsistence, or on the constitution of a labour-market. Wakefield, conscious of this, would advocate an identical programme for the white colonies. Even in the 'peasant nations' such as Egypt or India, there were sections of the bureaucracy that saw the proletarianisation of the peasantry as a certain and inevitable fate, as a process that had begun under its own rule and one that would proceed with the force of a natural law. This was one way of imparting a historical function to the famines that began to hit the peasantry more and more frequently towards the closing decades of that century.

But, in these 'peasant nations', capital followed a less obvious or more deceptive trajectory. As it happens, it was in a note to one of Wakefield's comments on the depressed condition of the Irish peasantry that Marx summed up this fundamental fact. He wrote, 'In this case profit is called rent, just as it is called interest when, for example, as in India, the worker (although nominally independent) works with advances he receives from the capitalist and has to hand over all the surplus produce to the capitalist'. ${ }^{16}$ By 'worker' Marx meant, of course, the peasant himself, and by 'capitalist', the monied bourgeoisie of moneylenders and merchants through whom the small producer was brought into relation with the market.

In 1859, Marx already implied that this relation was basically a capitalist one, but then with some uncertainty. Referring to the 'advance system', he wrote, 'In these cases, however, money functions only in the familiar form of means of purchase and therefore requires no new defi nition'. But he added, 'Of course, capital too is advanced in the form of money and it is possible that the money advanced is capital advanced...'. '.5 It makes a lot of difference which of these conceptions we accept, for, as Marx himself says, the latter 'does not lie within the scope of simple circulation'. That is to say, the 'advance' which a moneylender makes to the peasant is an advance of capital in the form of an advance of a certain sum of money or of the material elements of circulating capital (e.g., seed) and thus bearing the deceptive or illusory appearance of a pure 'loan'. Within a few years, it was this conception that Marx came around to accepting. Under this system, he wrote later, 'the producer pays the capitalist his surplus labour in the form of interest', or the capitalist receives 
his profi $\mathrm{t}$ in the form of interest, so that 'We have here the whole of capitalist production without its advantages...'..$^{166}$ That is, the labour-process, still being a process specifi $\mathrm{c}$ to the form of small-scale parcellised peasant-production, allowed no scope for a production of relative surplus-value or for the technical renovations presupposed therein. It follows also that domination by capital in this specifi c form (i.e., by a monied bourgeoisie) would force capital outwards in its drive to self-expand, force capital to extend the sphere of its domination laterally, to draw into its network an ever-growing mass of peasanthouseholds .

This would explain why so many of the peasant-struggles of this period (e.g., the Deccan Riots of 1875) were directed against the monied bourgeoisie and not against the colonial state, in which sections of the peasantry would in fact see a potential benefactor. But, again, because this was likewise a form of capitalist production that depended not on the constitution and automatic functioning of a labour-market, but on the coercive subjugation of the small commodity producer, the later historical empiricism of the Marxist tradition would simply isolate and concentrate on these relatively superficial elements of coercion and entirely ignore the inner content of the relationships they sustained. The widespread myth of 'semi-feudalism' is one of the legacies of this illusion. ${ }^{167}$

1 Engels 1959, pp. 39, 43. [See the bibliography in Theory as History, pp. 365ff.] 2 Marx 1971a, Volume 1, p. 27; Marx 1976, p. 101, from the 'Afterword' to the Second German edition.

3 Braudel 1972.

4 Vilar 1973, p. 67.

5 E.g., letter to Schmidt, 5 August, 1890 (Marx and Engels 1934, pp. 496-7).

6 That this conception underlay most Marxist historiography after the twenties is evident from Pecirka 1967. Practically every essay in this collection, for example, or in the CERM collection (1969) proceeds from the premise of verification. Yet these essays were characterized recently as 'important articles' (by Samir Amin). Only one

of the essays in fact showed a definitely critical and scholarly tendency:

Antoniades-

Bibicou 1969.

7 Cf. Colletti 1972.

8 Marx 1973, p. 109.

9 Plekhanov 1969.

10 Marx 1971a, Volume 1, p. 29, from the 'Afterword'; Marx 1976, p. 103.

11 Trotsky 1967, Appendix I, p. 428.

12 See Toulmin and Goodfield 1967.

13 Lukács 1968.

14 Toulmin and Goodfield 1967. 
15 Sartre 1960, p. 36.

16 Some of their key works are listed in the bibliography.

17 Stedman Jones 1972, p. 115.

18 In 1927 Henri Sée published a work entitled Matérialisme historique et

interpretations

économiques de l'histoire.

19 There were, of course, exceptions to this generalisation, e.g., E.A. Kosminsky,

Rodney Hilton. No detailed studies exist of the evolution of Annales and its

relationship

to Marxism.

20 Marx 1971a, Volume 3, pp. 334-5; Marx 1981, p. 452; all italics mine.

21 Marx 1973, p. 587.

22 Lenin 1963a, p. 438.

23 Marx 1973, p. 586.

24 Lenin 1963a, p. 466.

25 Marx 1971a, Volume 1, p. 305; Marx 1976, p. 439.

26 Marx 1971a, Volume 1, pp. 298-9; Marx 1976, p. 432.

27 Marx 1973, p. 726.

28 Marx 1971b, pp. 55, 430.

29 Marx 1970, p. 21 (from the 'Preface').

30 Marx 1973, p. 85.

31 Marx 1973, p. 98.

32 Marx 1973, p. 105.

33 Marx 1971a, Volume 2, pp. 36, 114; Marx 1978, pp. 120, 190. The fact that Marx tended to use Produktionsweise and Arbeitsprozess more or less interchangeably would

partly explain why the 'naturalist' conception of production which became widespread in the Second International and which passed, through Plekhanov, into Bukharin, for

example, was hardly ever directly challenged by those Marxists who assaulted its underlying philosophical premises, e.g., Gramsci. Lukács provides a partial exception

in his critique of Bukharin, Lukács 1966.

34 Marx 1968, p. 437.

35 Dobb 1963[1946], p. 35.

36 Dobb 1954, pp. 21, 24. As some of Sweezy's comments indicate, a certain confusion

prevailed in the debate about the content of the term 'serfdom'. (i) Marx himself tended to identify 'serfdom' specifi cally with the performance of labour-services, e.g.,

Theories of Surplus Value, pt. 3, p. 401. (ii) Historically, servage and villeinage were not organically linked to labour-services and only became so when the estates turned to commodity production (cf. Hilton 1969, p. 30). (iii) Dobb made the term suffi ciently elastic to mean by it not only labour services as such but 'the appropriation of tribute either in kind or in money' (Dobb in Sweezy et al. 1954). This confusing and historically

illegitimate conception of 'serfdom' directly contradicted Marx's conception, e.g., in 
the following statement from Theories of Surplus-Value: 'Serf-labour has this in common

with wage labour, in respect of rent, that the latter (rent) is paid in labour, not in products, still less in money', Marx 1971b, p. 401. (my emphasis)

37 Dobb 1963 [1946], p. 7.

38 Duby 1968, pp. 262-3.

39 Marx 1973, p. 100.

40 Marx 1973, p. 463 (emphasis added).

41 Sweezy 1954, p. 1.

42 Dobb 1954, p. 21, n. 1.

43 In Studies, he does characterise the increasing use of hired labour by such estates as the emergence of a 'new mode of production', i.e., capitalism (Dobb 1963 [1946], p. 55).

44 Cf . Blum 1968, pp. 271-2. According to Bloch 1963, p. 214, slaves were a 'normal element of nearly every seigneurie' in the early feudal period.

45 Lenin 1963b, p. 216.

46 Lenin 1963a, p. 484 (emphasis added).

47 Palloix 1971, pp. 74-5 simply fails to understand this process when he argues that, as long as the peasant remains tied to the means of production, capital appropriates his surplus-labour on the basis of the old feudal relations of production: 'le processus de quasi-intégration de l'atelier agricole par le marchand drapier laisse subsister des anciens rapports féodaux tant que ce procès n'aboutit pas à la prolétarisation du paysan'. On the contrary, Marx spoke of the artisans being 'turned into mere wageworkers

and proletarians', and referred, elsewhere, to the means of production which were left to the small producer by capital as 'sham property'. Palloix cites Capital, Volume III, (Marx 1981, pp. 452-3) to substantiate his view, thus ignoring the fact that,

in this passage, as in so many others, Marx meant by 'mode of production' only the labour-process of the small producer. (See Section 7 below for a fuller analysis.) Amin 1976, is correct to point out that peasants who produced under these conditions were wage-workers, but he abolishes this insight in Amin 1974, when, in the short chapter

on 'modes of production', he writes that the internal disintegration of simplecommodity production into capitalism was an 'absolute law' of this form of economy.

48 Lenin 1963a, p. 414.

49 Kautsky 1970, p. 25.

50 Marx 1971a, Volume 1, pp. 226-7; Marx 1976, p. 345.

51 Luxemburg 1972, pp. 55-6.

52 Preobrazhensky 1965, p. 185.

53 Marx 1971a, Volume 3, p. 332; Marx 1981, p. 449.

54 Pokrovsky 1931, p. 287.

55 Mariátegui 1971, p. 55, ‘But on the coast, the latifundium has reached a fairly advanced level of capitalist technique, although its exploitation still rests on feudal 
practices and principles. The yields of cotton and sugar cane are those of the capitalist system. Enterprises are heavily fi nanced and land is worked with modern machines and methods'.

56 Degras 1971, Volume 1, p. 384; Carrère d'Encausse and Schram 1969, p. 194, with a slightly different translation: 'To the extent that capitalism in the colonial countries arises on feudal foundations, and develops in distorted and incomplete transitional forms, which give predominance to commercial and usurious capital (the Muslim East, China)...'.

57 Hobson 1917, p. 13, where he states that, under colonial economy, '[t]rading profi ts were supplemented by the industrial profi ts representing the "surplusvalue" of slave or forced labour'.

58 Moore 1966, p. 495.

59 Engels 1968.

60 Marx 1971a, Volume l, p. 28; Marx 1976, p. 101. This principle of 'historical specificity' was central to Korsch's interpretation of Marx, cf. Korsch 1963.

61 Thus Marx wrote of Sismondi that he 'forcefully criticizes the contradictions of bourgeois production, but does not understand them...' (1971b, p. 56).

62 Frank 1969; Laclau 1971.

63 Marx 1973, p. 512.

64 E.g., Trapido 1971; Van Zwanenberg 1971.

65 Dobb 1954, p. 24; Laclau 1971.

66 Frank 1969.

67 Bettelheim 1972, p. 300.

68 Arrighi 1970; Amin 1974; Amin 1976.

69 Marx 1971a, Volume 2, p. 36; Marx 1978, pp. 119-20; Marx 1971a, Volume 3, p. 331f.; Marx 1981, p. 449.

70 Laclau 1971, p. 37; Laclau 1977, p. 40.

71 Laclau 1971, p. 30; Laclau 1977, p. 30.

72 Marx 1968, p. 239.

73 Marx 1968, pp. 302-3.

74 Marx 1974a, Volume 1, pp. 226-7; Marx 1976, p. 345.

75 Preobrazhensky 1965, p. 185.

76 Kautsky 1970, p. 205.

77 Lenin 1964b, pp. 30, 50; italics in original.

78 Genovese 1970, p. 69.

79 Genovese 1966, p. 23. This confusion or ambiguity is found outside Marxist writings as well: with reference to Mexico, François Chevalier described the coastal sugar-plantations of New Spain as 'the first great feudal estates' which, as early as the sixteenth century, 'anticipated the classical Mexican hacienda' (Chevalier 1963, pp. 81ff.). On the other hand, to Lewis Gray, in a major work on the economics of American

slavery, the plantation was a 'capitalistic type of industrial organization' based on a mass of unfree labourers (Gray 1933, p. 302; italics in original). Dunn states in his 
sensitive social history that, when the English planters of Barbados turned to sugar production, 'their prime goal was to make money, not to become seigneurs...'

(Dunn, 1973, p. 65). To the 'new economic historians' of the USA, the econometric study of

Conrad and Meyer was a decisive blow against 'the attempt to portray slaveowners as a "pre-capitalist" or "acommercial" class which failed to respond to modern business

incentives' (cf. Fogel and Engerman 1971, p. 326). Finally, Samir Amin refers to the plantations as a 'slave owning mode of production' but adds that it should not be confused with the 'true' one (Amin 1974, Volume 2, p. 361).

80 Mandle 1972.

81 In other words, it is taken for granted, as I said earlier, that no form of forced labour can mediate capitalist relations of production. Cf. M.V. Freyhold, 'The Rise and

Fall of Colonial Modes of Production': 'When the representatives of early capitalism started looking around the world for chances of appropriating the surplus-labour of other peoples, they soon realized that "free labour" was not available outside Europe.

Any exploitation elsewhere would have to be based on forced labour of some kind. Capitalist production was out of the question'. The characterisation of the mode of production as 'colonial' which I myself accepted earlier, much too hastily, suspends the problem even more than either of the traditional characterisations.

82 Lenin 1956, pp. 178-9.

83 'Economies of scale': in Barbados c. 1646 an average sugar plantation probably required an investment close to $£ 2,500$ (computed from data in Dunn 1973), which should be compared with Dobb's data on the scale of investment in seventeenth century

British industry (Dobb 1963 [1946], Chapter 4). In Jamaica, by the eighteenth century, the average value of such a plantation was $£ 20,000$ according to Sheridan 1965.

84 Cf. Genovese 1966, p. 16, 'the greater part of slavery's profits find their way back into production (but) economic progress is quantitative...'. 85 In Marx's chapter on 'Absolute Ground-Rent', Marx 1981, Chapter 45, it is the technical proportion of living labour to the conditions of labour that determines the relation of the price of production to value. Thus the problem of how the 'organic composition of capital' can be determined for a capitalist slave-economy does not affect the hypothesis proposed.

86 This is implied by Marx when he writes that as long as 'the elemental profusion of land...offers no resistance to capital investment', 'nothing will stand in the way of

cost-price regulating market-value': Marx 1968, p. 303. We know that this condition would apply only in the early stages of settlement.

87 Pares 1960; Sheridan 1965.

88 Cf. Davies 1954.

89 Braudel and Spooner 1967.

90 Pokrovsky 1931, p. 261.

91 Małowist 1959.

92 Fisher 1971. 
93 Data on productivity collected from: Duby 1968, pp. 101-2 ; Woolf 1964-5, p. 268ff.; Blum 1968, p. 329.

94 Kula 1970.

95 This point, emphasised by Kula, is already to be found in Richard Jones (Jones 1831) who, precluding the possibility of rapid technical advances under feudalism, argued that

rent could only be increased 'by an increase in the total quantity of labour exacted, and in this case while the lands of the proprietor will be better tilled those of the serfs, from which labour has been withdrawn, all the worse' (cited Marx 1971b, p. 400).

96 Lenin 1963b, p. 189; Lenin 1963a, pp. 450, 493.

97 Kula 1970.

98 Pirenne 1969, p. 56.

99 Duby 1973, p. 200.

100 Sweezy 1954, p. 9.

101 Duby 1968, p. 136.

102 Duby 1968, p. 211.

103 Britnell 1966.

104 Confino 1963, p. 131.

105 Confino 1963, p. 138.

106 As Sweezy tended to imply they were, after correctly stating that his conception of feudalism as a 'system of production for use' did not preclude the possibility of estates producing for the market .

107 A.L. Komarov, cited by Confino 1963, p. 141.

108 Levett 1927.

109 The point is stressed by Confino 1963, who sees in this a transposition, to the feudal estates, of the economic logic of small-peasant production.

110 Kula 1970.

111 Duby 1968, pp. 262-3.

112 Małowist 1959.

113 Duby 1973.

114 Kula 1970, p. 109.

115 The connection between obrok and otchod is drawn out by Confino 1963.

116 Duby 1968, p. 286.

117 The proportion $80 \%$ is calculated by combining Postan's data on the sizedistribution

of holdings (Postan 1972, p. 130) with Titow's calculation of the size of a 'subsistence plot' (Titow 1969). Conditions in the thirteenth-century English countryside

would thus have been comparable to the condition of India's peasantry today, except

that the possibilities of employment may have been greater.

118 Blum 1968, p. 206.

119 Marx 1971a, Volume 2, pp. 33-4; Marx 1978, p. 117.

120 Duby 1968, pp. 53-4; Duby 1973, pp. 51-2, 105.

121 Kosminsky 1935.

122 Pach 1966.

123 Blum 1957.

124 Kosminsky 1935, p. 40. 
125 Confino 1963.

126 Kula 1970; Pach 1972.

127 Bautier 1971, p. 192.

128 Pokrovsky 1931, p. 116.

129 Keith 1971, p. 435. Keith, however, sees the connection with the market as suffi cient for calling the hacienda a 'capitalist institution'.

130 Bauer 1971; 1972.

131 Twitchett 1962, p. 31.

132 Elvin 1973.

133 Weber 1961, p. 82.

134 Cf. Painter 1943.

135 Dobb 1963 [1946], p. 42.

136 Blum 1968, p. 221.

137 Miller 1971, p. 11.

138 Kula 1973, p. 76.

139 Duby suggests that such a decline was already evident in Europe some four decades before the Plague. For further evidence of declining population well before the Plague, see Herlihy 1965.

140 If we take the rural economy of Russia, for example, on the eve of the emancipation,

it was characterised by (i) a predominance of landlords on the grain-market,

(ii) a serf-population of which $70 \%$ had been mortgaged to government creditbureaux,

(iii) an absolute decline in the serf-population, (iv) a buoyant market in serf-labour; cf. Blum 1968, Chapters 20-21. It should be emphasised that the 'model' proposed abstracts from all supplementary and contingent factors in order to reveal the process in its essential form: notably, it abstracts from (a) the intervention of the state, which could radically modify or restrain this whole process, as in China or Byzantium,

(b) the crises specifi c to the old biological time, e.g., the Black Death which inaugurated

the decay of feudal economy in the West, (c) the territorial expansion of capitalist powers.

141 Marx 1973, p. 469.

142 Vilar 1971.

143 Małowist 1972, p. 106.

144 The form was variously called the 'rural-patriarchal system of production' by Marx 1970, p. 33; 'die Kleinproduktion in der Landwirtschaft' by Engels (letter to Danielson, 15 March 1892, in Marx and Engels 1968, p. 304); and the 'peasant mode of production' by Kautsky 1970, p. 317.

145 Marx 1971a, Volume 3, p. 690; Marx 1981, p.829.

146 Marx 1971a, Volume 3, p. 805-6; Marx 1981, pp. 941-2.

147 Marx 1971a, Volume 3, p. 806; Marx 1981, p. 942.

148 Lenin 1964a, p. 124; Kautsky 1970, p. 365.

149 Marx 1968, p. 302.

150 Lenin 1963a, pp. 482-3.

151 Marx 1973, p. 510.

152 Lenin 1956, p. 473, 'quasi-independent producers'. 
153 Lenin derived the small producer's dependence from the inherently monopsonistic position of merchant-capital in conditions of large-scale marketing, Lenin 1956, p. 387. He spoke of 'a necessary causal connection between small production for the market and the domination of merchant capital', ibid., p. 389.

154 The now classic examples of this form of enterprise are: the Société Commerciale de l'Ouest Africain; the Compagnie Française d'Afrique Occidentale; the United Africa

Company; The British East Africa Corporation; Ralli Brothers; the Assam Company; Binny \& Co.; Boustead \& Co.

155 Engels to Bebel, 11 December, 1884.

156 Cf . Rubin 1972, p. 37ff., for this principle of Formbestimmtheit in Marx.

Translating

the central thesis of the essay into these terms, we could say: forms of exploitation derive their specifi c historical 'social forms' and 'functions' from the relations of production which they mediate or which are embodied in them. When simple abstractions are confused for concrete categories, when they are not yet subjected to a process of further abstraction which is a process of their concretisation, the specifi c

forms and functions which compose their historical content in any given situation are left 'indeterminate'. We can see, therefore, that there is a close and essential connection between Marx's pages on the 'method of political economy' in the Grundrisse (where the notions of 'simple' and 'concrete' categories figure) and the principle of 'form-determination', which figures in a practical way in the analysis of money. 157 Chowdhury 1964, pp. 129-34.

158 Chowdhury 1964, p. 162.

159 There is no obvious reason why the 'dual-economy' thesis could not be modifi ed to incorporate the image of a 'traditional sector' not simply coexisting with the 'modernising' one, but actually relating to it through various forms of dependence and domination. In this sense, Laclau's critique of Frank (Laclau 1971) and Arrighi's critique of Barber (Arrighi 1970) do not actually transcend the thesis, but only render it more sophisticated.

160 For historically concrete analyses of this form, see Chowdhury 1964; Mamdani 1976.

161 Marx 1971a, Volume 2, p. 36; Marx 1978, p. 120.

162 Preobrazhensky 1965, p. 186.

163 Marx 1971b, p.487.

164 Marx 1971b, p. 188.

165 Marx 1970, p. 140.

166 Marx 1971b, p. 487.

167 I shall argue this in detail elsewhere, on the basis of the superbly informative British sources that cover this period for India. (See Theory as History Chapter 10.) 